\title{
Rift Valley fever virus (Bunyaviridae: Phlebovirus): an update on pathogenesis, molecular epidemiology, vectors, diagnostics and prevention
}

\author{
Michel Pepin ${ }^{1,2 *}$, Michèle Bouloy ${ }^{3 \dagger}$, Brian H. BIRD ${ }^{4}$, Alan KemP ${ }^{5}$, \\ Janusz PAWESKA 5 \\ ${ }^{1}$ AFSSA site de Lyon, 31 avenue Tony Garnier, F-69364 Lyon Cedex 7, France \\ ${ }^{2}$ VetAgro Sup, Campus Vétérinaire de Lyon, 1 avenue Bourgelat, F-69280 Marcy L’Etoile, France \\ ${ }^{3}$ Institut Pasteur, Unité de Génétique Moléculaire des Bunyavirus, 25 rue du Dr Roux, \\ 75724 Paris Cedex, France \\ ${ }^{4}$ Centers for Disease Control and Prevention (CDC), Special Pathogens Branch, 1600 Clifton Rd, \\ Mailstop G-14 SB, Atlanta, GA 30333, USA \\ ${ }^{5}$ Special Pathogens Unit, National Institute for Communicable Diseases, National Health Laboratory Service, \\ Private Bag X4, Sandrigham 2131, Republic of South Africa
}

(Received 5 February 2010; accepted 21 May 2010)

\begin{abstract}
Rift Valley fever (RVF) virus is an arbovirus in the Bunyaviridae family that, from phylogenetic analysis, appears to have first emerged in the mid-19th century and was only identified at the begininning of the 1930s in the Rift Valley region of Kenya. Despite being an arbovirus with a relatively simple but temporally and geographically stable genome, this zoonotic virus has already demonstrated a real capacity for emerging in new territories, as exemplified by the outbreaks in Egypt (1977), Western Africa (1988) and the Arabian Peninsula (2000), or for re-emerging after long periods of silence as observed very recently in Kenya and South Africa. The presence of competent vectors in countries previously free of RVF, the high viral titres in viraemic animals and the global changes in climate, travel and trade all contribute to make this virus a threat that must not be neglected as the consequences of RVF are dramatic, both for human and animal health. In this review, we present the latest advances in RVF virus research. In spite of this renewed interest, aspects of the epidemiology of RVF virus are still not fully understood and safe, effective vaccines are still not freely available for protecting humans and livestock against the dramatic consequences of this virus.
\end{abstract}

Rift Valley fever / molecular epidemiology / vector / pathogenesis / diagnostic

\section{Table of contents}

1. Introduction.

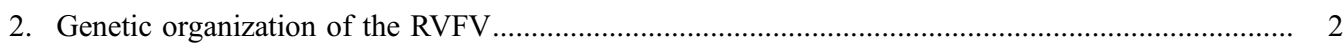

2.1. Structure of RVF virion and its genome.

\footnotetext{
$\bar{\dagger}$ The findings reported here are those of the author and do not necessarily represent those of the Centers for Disease Control and Prevention.

* Corresponding author: m.pepin@afssa.fr or m.pepin@vetagro-sup.fr

This is an Open Access article distributed under the terms of the Creative Commons Attribution-Noncommercial License (http://creativecommons.org/licenses/by-nc/3.0/), which permits unrestricted use, distribution, and reproduction in any noncommercial medium, provided the original work is properly cited.
} 
2.2. The viral replication cycle: role and function of viral genes and their products...... 3

2.3. The nonstructural proteins and their role in evasion of the innate immune response............... 7

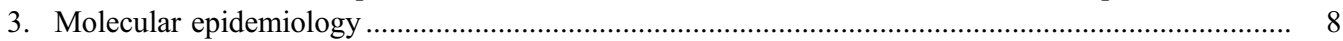

3.1. Influence of widespread virus movement, reassortment and introduction across natural

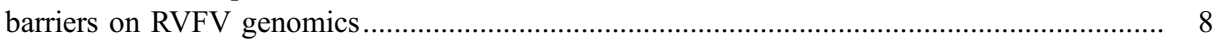

3.2. Genomic diversity and molecular evolutionary rate …......................................................... 10

3.3. Recent ancestry and the influence of environmental change ............................................. 10

3.4. Insights into RVFV molecular epidemiology from the east African 2006-2007 outbreak ....... 11

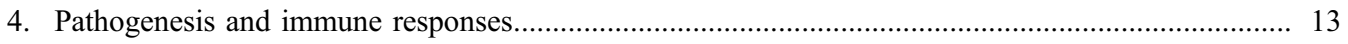

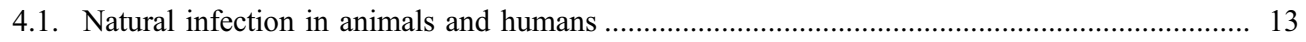

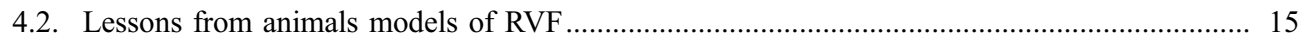

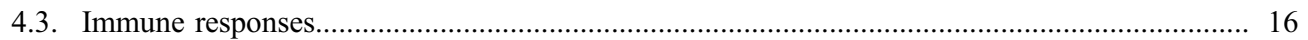

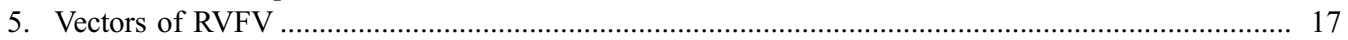

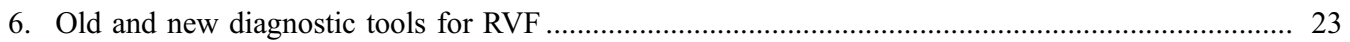

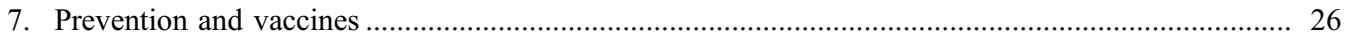

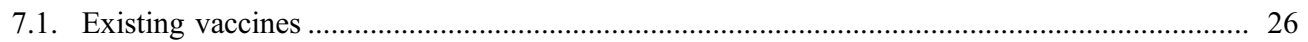

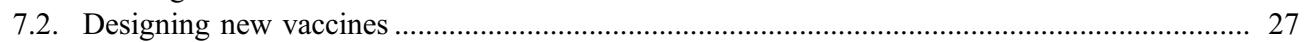

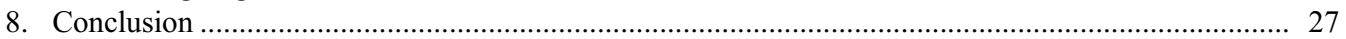

\section{INTRODUCTION}

Rift Valley fever virus (RVFV; Bunyaviridae: Phlebovirus) is primarily transmitted by mosquitoes and causes a potentially severe disease among both humans and animals. The virus was first identified in 1930, during an outbreak of sudden deaths and abortions among sheep along the shores of Lake Naivasha in the greater Rift Valley of Kenya [51, 52]. The geographic distribution of the virus has since grown significantly and now includes most countries of the African continent and Madagascar [100]. It emerged for the first time outside Africa in the Arabian Peninsula in 2000-2001 and caused a large outbreak in livestock and humans [11]. More recently, it was detected for the first time in the Archipelago of Comores, located between Mozambique and Madagascar, on the French Island of Mayotte [242]. Due to the increasing range of the virus, the high numbers of competent vector species present in currently RVF-free regions, such as Europe [199] and the USA [95, 266], the intensification of international trade in live animals, and the unknown impact of climate change, several national and international agen- cies have issued warnings about the heightened risk of introduction of RVFV into RVF-free countries [27, 37, 57, 69, 92, 140, 170, 224, $229,280,291]$. These reports conclude unanimously that coordinated efforts to better prepare for a possible emergence of RVFV are needed.

This review provides a comprehensive update on RVFV, with particular attention devoted to the molecular epidemiology, virus genetics, vectors, diagnostic techniques and the pathogenesis of this significant veterinary and public health threat $[22,26,85$, 100, 253].

\section{GENETIC ORGANIZATION OF THE RVFV}

Like all bunyaviruses, RVFV is an enveloped RNA virus characterized by a genome composed of three segments designated L, M and $\mathrm{S}$ of negative or ambisense polarity. All the replication steps occur in the cytoplasm of infected cells and virions mature by budding in the Golgi compartment [207]. 


\subsection{Structure of RVF virion and its genome}

\subsubsection{The virion}

Early ultrastructural studies by electron microscopy and negative staining described RVFV particles measuring 90-110 nm in diameter [77]. The envelope is composed of a lipid bilayer containing the $G_{n}$ and $G_{c}$ glycoproteins forming surface sub-units, $5-8 \mathrm{~nm}$ in length, regularly arranged on its surface, similar to those reported for the related Uukuniemi phlebovirus [273]. The viral ribonucleoproteins (RNP) corresponding to each of the three genomic segments, associated with numerous copies of the nucleoprotein $\mathrm{N}$ and the RNA dependent RNA polymerase $\mathrm{L}$, are packaged into the virion. More recent studies by cryo-electron microscopy on Uukuniemi virus and RVFV have modified the former view that phleboviruses are pleiomorphic [89, 118, 212, 238]. Instead these studies indicated that virions are likely to have an icosahedral symmetry: the structure is highly ordered and the surface covered by a shell of 120-122 glycoprotein capsomers arranged in an icosahedral lattice with $T=12$. Three dimensional reconstructions at 22 or $27 \AA$ resolution revealed that the capsomers resemble hollow cylinders situated at fiveand six-coordinated positions. Inside the envelope, a layer of RNP is located proximal to the inner leaflet of the membrane, strongly suggesting an interaction between the cytosolic tail of the glycoproteins and the RNP which would compensate for the absence of matrix protein in the viruses of this family.

\subsubsection{The viral genome}

The RVFV genome is composed of three segments, L, M and S, which are presumed to be packaged together in the virions in the form of RNP. Sequencing indicated that the $3^{\prime}$ and $5^{\prime}$ terminal sequences are complementary to each other, forming panhandle structures, and explains the finding that RNP are circular when observed by electron microscopy [75]. The L and $\mathrm{M}$ segments are of negative polarity, coding respectively for the $\mathrm{L}$ protein, which is the viral RNA-dependent RNA polymerase [200], and for the precursor to the glycoproteins [46, 47]. The $\mathrm{S}$ segment utilizes the ambisense strategy to code for two proteins, the nucleoprotein $\mathrm{N}$ and a nonstructural protein called NSs [104]. The coding capacity of the genome is depicted in Figure 1. The general view that only the viral genome is incorporated into the mature particle has been revisited since a small but significant fraction of the antigenomes i.e. replicative intermediates have been detected in purified RVFV particles [123]. These data correlate with past studies on Uukuniemi virus showing that the $\mathrm{S}$ segment of genomic and antigenomic polarities could be detected in purified virions [241].

\subsection{The viral replication cycle: role and function of viral genes and their products}

\subsubsection{Transcription and replication}

The general features of RVFV transcription and replication are similar to those of other negative stranded RNA viruses [74, 75]. During the replication cycle, each segment is transcribed into mRNA and is replicated through a process which involves the synthesis of the exact copy of the genome, called complementary RNA (cRNA) or antigenome. For phleboviruses, and RVFV in particular, the cRNA representing the copy of the $\mathrm{S}$ ambisense segment serves as a template for the synthesis of the NSs mRNA. Since the S cRNA is present in the input virus, the protein is expressed early, a good indication that it has an important role during infection. Messenger RNA synthesis is initiated through a cap-snatching mechanism whereas the synthesis of cRNA is initiated with $5^{\prime}$ nucleoside triphosphates. Furthermore, cRNA is the complete copy of the vRNA whereas mRNAs terminate in the non-coding region before the $5^{\prime}$ end of the template for the $\mathrm{L}$ and $\mathrm{M}$ segments or in the intergenic region for the $\mathrm{S}$ segment. The switch between the two activities of the L polymerase remains unknown; although several polymerase consensus motifs were found in the L protein [200], the different domains of the $\mathrm{L}$ protein responsible for the activities of capsnatching or transcription termination have not been determined yet. 

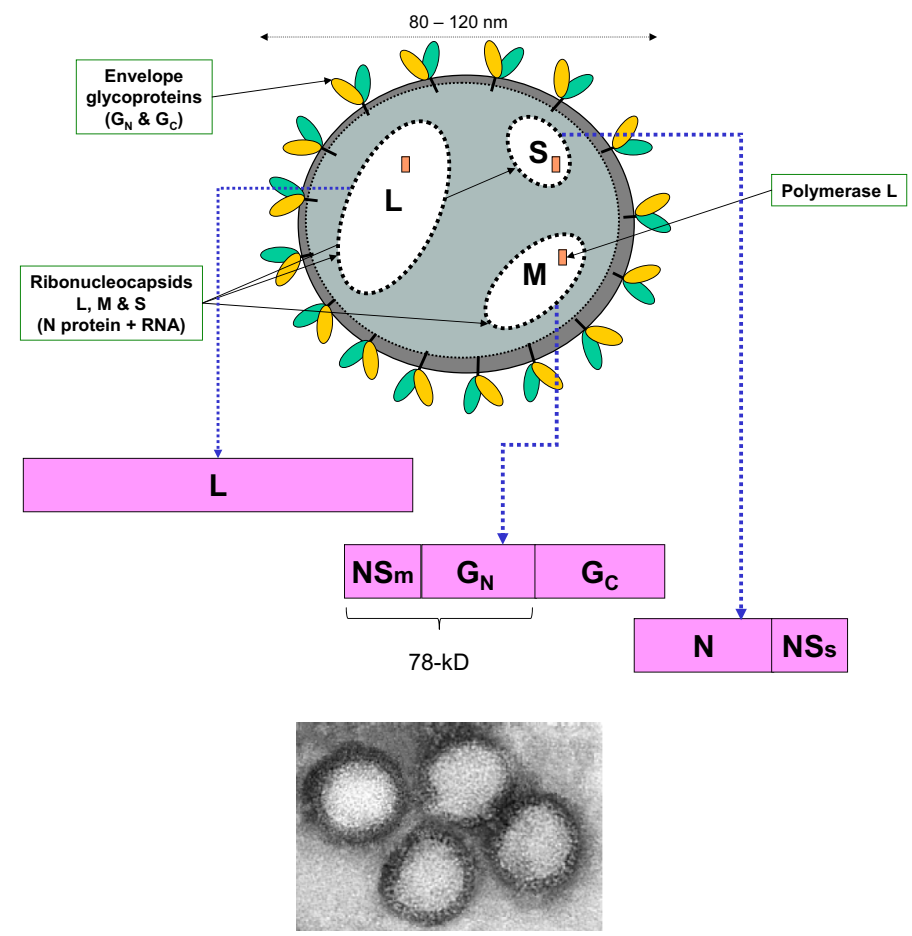

Figure 1. Schematic diagram of Rift Valley Fever virus (electron micrograph from Linda Stannard [258]). (A color version of this figure is available online at www.vetres.org.)

Systems to manipulate the RVFV genome and allow for the rescue of infectious viruses from cDNA have now been established by several different groups [17, 103, 107, 124]. Besides being an essential step in the development of reverse genetics, minigenomes mimicking a genome segment in which the viral ORF is replaced by a reporter gene have been helpful to analyze various steps in RNA synthesis, i.e. transcription, replication, transcription termination and packaging. Minigenomes can be expressed from T7 or Poll promoter-based plasmids. Expression under the control of the T7 promoter requires transfection in cells expressing the T7 RNA polymerase such as the BSR-T7/5 [48] or BHK/T7-9 cells [129] whereas expression from the Poll promoter is species specific so that the cells used for the study must correspond to the species of the promoter sequence [205]. Studies with minigenomes clearly established that transcription and replication of the viral-like RNA requires the expression of the $\mathrm{N}$ and $\mathrm{L}$ proteins, which are necessary to reconstitute RNP, thus confirming the concept [161] that naked RNA cannot be transcribed. These data also indicate that $\mathrm{L}$ protein by itself or in association with $\mathrm{N}$ is able to assume both transcription and replication, excluding the possibility that the $\mathrm{L}$ protein had to be modified by a viral factor to function as a replicase. One should note however, that the RVFV NSs was reported to promote viral RNA replication and transcription in a minigenome system [122] but this particular characteristic was not confirmed ${ }^{1}$; instead, RVFV NSs was found to be inhibitory, like the NSs of the related Bunyamwera virus [281]. This difference may be due to the experimental conditions utilized by the two groups: RVFV

\footnotetext{
${ }^{1}$ Bouloy M., unpublished data.
} 
minigenome expression as a T7 versus Poll transcript in 293 versus BSR cells.

When compared to each other, the L, M and $\mathrm{S}$ segment-based minigenomes do not express identical levels of reporter gene, indicating differential promoter activities associated with the non-coding regions [97]. Although the mutagenesis was not as extensive as the one carried out for Uukuniemi virus [84], it appeared that some of the conserved nucleotides in the noncoding regions, particularly the first 8 terminal nucleotides and the purine at position 13, play an important role in promoter activity and the regulation of gene expression [226].

In contrast with most viral or cellular mRNA, bunyavirus mRNA are not polyadenylated. The M segment derived mRNA of the Sin Nombre hantavirus seems to be the only exception reported to date [120]. The bunyaviral mRNA terminate prematurely on their template, strongly suggesting that the transcriptases recognize a transcription termination signal. Preliminary data suggested that a conserved motif is present in the intergenic region of the $\mathrm{S}$ segment of Toscana, sandfly fever Sicilian and RVF viruses [104, 106], contrasting with other ambisense viruses where RNA hairpin structures serve as termination signals [162]. To further understand the termination process, Albarino et al. [3] mapped precisely the $3^{\prime}$ end of the 4 RVFV mRNA: N mRNA, NSs mRNA and the $\mathrm{M}$ - and L-derived mRNA, and identified a conserved sequence motif " 3 ' $-\mathrm{C}_{1-3}$ GUCG/A" on both $\mathrm{M}$ and ambisense $\mathrm{S}$ segment sequences of several phleboviruses of the sandfly serogroup. To demonstrate the role of this sequence, they created a recombinant RVFV lacking the termination motif in the $\mathrm{S}$ segment by reverse genetics. Analysis of the mRNA synthesized in the cells infected with this mutated virus showed that the transcriptase failed to terminate the $\mathrm{S}$ mRNA correctly. Using a method of RNase protection assays to map the $3^{\prime}$ end, Ikegami et al. [125] came to a similar conclusion on the termination of the $\mathrm{S}$ and $\mathrm{M}$ segments. However, the two reports presented conflicting data on the $\mathrm{L}$ segment, which lacks the pentanucleotide motif in the $5^{\prime}$ non-coding region. Albarino et al. [3] reported that L mRNA represents the complete copy of its template whereas Ikegami et al. [125] claimed that the L mRNA lacks the last 16-41 nucleotides when compared to the fulllength cRNA copy and that the termination signal corresponds to two 13-nucleotide-long complementary sequences present in the $5^{\prime}$ non-coding region of the $\mathrm{L}$ genomic segment.

\subsubsection{The glycoproteins and their role in cell entry and particle formation}

During the viral cycle, the glycoproteins play an essential role for the penetration of the virus and their proper processing is crucial for the maturation and budding of the virion. The glycoproteins, being the most exposed components of the virus during infection, are recognized by the immune system and induce the production of neutralizing antibodies, which play a predominant role in protection. The glycoproteins also mediate virus entry into many cell types through specific receptors which, in the case of RVFV and many other bunyaviruses, remain to be identified. Entry is predicted to employ a class II fusion mechanism that is activated by low $\mathrm{pH}$ following endocytosis of the virion [82]. Little is yet known regarding the early phases of infection that precede the release of virus RNP into the cytosol.

The RVFV M segment codes for a polyprotein precursor which, after cleavage, generates $G_{n}$ (encoded by amino-terminal sequences of the precursor) and $\mathrm{G}_{\mathrm{c}}$ (encoded by carboxyterminal sequences) as well as two nonstructural proteins, the $78 \mathrm{kDa}$ (also called NSm1) and the $14 \mathrm{kDa}(\mathrm{NSm} 2)$ proteins. The question was raised of whether the $78 \mathrm{kDa}$ protein is a structural protein [227], but a more recent work indicated that this protein was not detected in purified particles [89]. The NSm1 and NSm2 nonstructural proteins are produced by alternative use of the first or the second of the 5 in-frame AUG codons present at the $5^{\prime}$ end of the M mRNA and located upstream of the $G_{n}$ sequence (Fig. 2). The first AUG initiates the synthesis of the $78 \mathrm{kDa} \mathrm{NSml}$ product which includes the sequence of $G_{n}$ while the second AUG is utilized for the synthesis of the $14 \mathrm{kDa} \mathrm{NSm} 2$ which terminates before $\mathrm{G}_{\mathrm{n}}$. The first and fourth AUG precede 
(A)

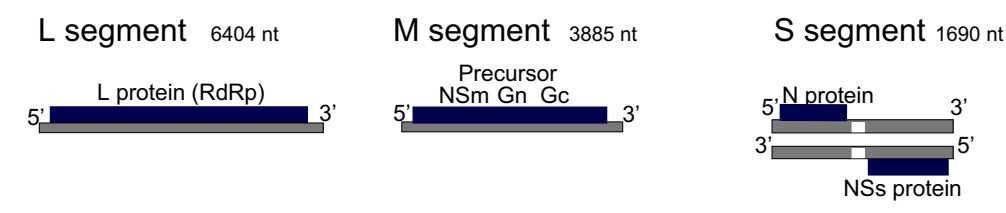

(B)

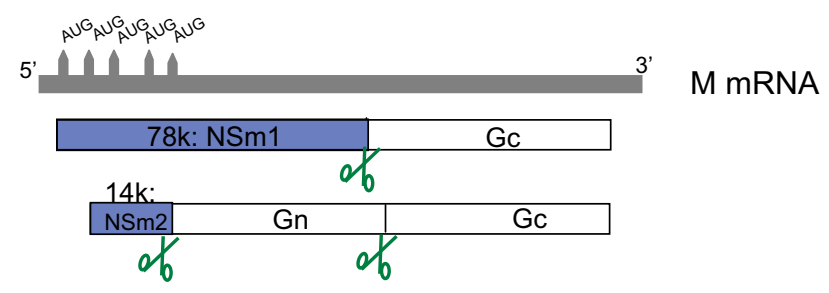

Figure 2. (A) Schematic representation of the Rift Valley fever virus genome. The antigenomic sense RNA and the encoded open reading frames (blue box) are represented. For the ambisense $\mathrm{S}$ segment, the genome and its open reading frame are represented (below). (B) Schematic diagram of the mRNA transcribed from the segment $\mathrm{M}$ of Rift Valley fever virus. (A color version of this figure is available online at www.vetres.org.)

a sequence typical for signal peptides, suggesting that $\mathrm{NSm} 1$ and $\mathrm{G}_{\mathrm{n}}$ could be directed to the endoplasmic reticulum (ER). Wasmoen et al. [278] showed that, regardless of the presence of NSm1 and NSm2, $\mathrm{G}_{\mathrm{n}}$ and $\mathrm{G}_{\mathrm{c}}$ are localized in the Golgi complex, suggesting that the signals for Golgi localization reside in $G_{n}$ and/or $\mathrm{G}_{\mathrm{c}}$. However, when expressed in the absence of $G_{n}, G_{c}$ localizes to the ER due to the presence of a lysine-based ER retrieval signal at its $C$ terminus [101]. This suggests that $G_{c}$ moves to the Golgi apparatus via its physical association with $\mathrm{G}_{\mathrm{n}}$. Localization of the glycoproteins in the Golgi complex is essential for proper maturation of the bunyavirus particles which bud into the lumen of the Golgi. RVFV-infected hepatocytes seem to represent the only known exception as budding of particles was observed to occur at the plasma membrane as well as at the Golgi vesicles [5]. Late in infection, in most vertebrate cells, the Golgi complex undergoes morphological changes, with vacuolization and dispersion of small and large vesicles in the cytoplasm. Virions are then transported within these vacuoles to the cell surface where fusion of the vacuole and plasma membranes allows for the release of virus into the extracellular medium.

Minigenome systems, developed to assess transcription and replication activity, were also used to evaluate packaging activity. The glycoproteins, which are co-expressed together with the transcription machinery, allow formation of the viral like particles (VLP) which are released into the medium [108]. When observed by electron microscopy and negative staining, these particles resemble RVFV particles in size and morphology. They were able to infect naïve cells and to undergo the first step of the replication cycle, i.e., primary transcription. If both $\mathrm{L}$ and $\mathrm{N}$ are provided in trans, replication of minigenomes occur [204]. Interestingly, similar RVFV VLP were produced in insect cells infected with a dual baculovirus vector expressing $\mathrm{G}_{\mathrm{n}} / \mathrm{Gc}$ glycoproteins and the $\mathrm{N}$ protein. Another vector expressing $N$ and only $G_{c}$ was constructed but was found to produce particles of a more pleiomorphic nature, suggesting that both $G_{n}$ and $G_{c}$ contribute to the assembly process and likely interact with $\mathrm{N}$ [159]. 


\subsection{The nonstructural proteins and their role in evasion of the innate immune response}

\subsubsection{The role of $\mathrm{NSS}$ in virulence}

Remaining undetermined for many years, NSs has been identified as a major factor of virulence, primarily characterized as an interferon antagonist. The molecular mechanisms sustaining this phenomenon involve several cellular proteins interacting with NSs. One of them, SAP30 belongs to the $\mathrm{Sin} 3 \mathrm{~A} / \mathrm{NCoR} / \mathrm{HDAC}$ repressor complexes which intervene in gene transcription regulation. Moreover, it was shown that SAP30 interacts directly with YY1, a transcription factor involved in the regulation of expression of numerous genes, including IFN- $\beta$ [151]. Through a series of co-immunoprecipitation confocal microscopy and chromatin immunoprecipitations, it was demonstrated that NSs, SAP30, YY1, HDAC3 and $\operatorname{Sin} 3 \mathrm{~A}$-associated corepressor factors are recruited on the IFN- $\beta$ promoter, excluding CBP (a coactivator known as CREB binding protein) loading and preventing histone acetylation and transcriptional activation. To ascertain the role of NSs interacting with SAP30 in this mechanism, a recombinant ZH548 RVFV, containing the specific domain of NSs required for the interaction with SAP30, was produced by reverse genetics. In contrast with the virulent ZH548 RVFV, this mutant, ZH548-NSs $\Delta 210$ 230 , was able to induce IFN- $\beta$ expression and was avirulent in the mouse model.

Efforts made during the last few years to investigate the role of NSs led to the concept that it is a multifunctional protein, enabling RVFV to evade the host antiviral response. A strategy to circumvent the host response relies on the interaction of the p44 subunit with the TFIIH basal transcription factor, which is sequestered by the NSs filamentous structure so characteristic of RVFV infection [50, 150]. As a consequence TFIIH cannot assemble and its concentration drops rapidly, explaining the drastically reduced transcriptional activity of cells infected with RVFV expressing NSs. Interestingly the two functions of NSs complement each other: first, the specific inhibition of IFN- $\beta$ gene transcription is implemented as early as 3-4 h post-infection (p.i.) a time at which IFN- $\beta$ would normally be synthesized. Later during the replication cycle, at a relatively late time (after $8 \mathrm{~h}$ p.i.), a second mechanism mediated through the interaction of NSs and TFIIH takes place to inhibit the general transcription of the infected cells.

The RVFV NSs protein is unique among bunyaviruses as it forms a filamentous structure in the nucleus, which is unexpected for a virus replicating in the cytoplasm [248, 250]. Investigations into the formation of the NSs filament showed that cellular DNA is predominantly excluded from NSs filaments except for some specific DNA regions of the host genome such as clusters of a pericentromeric gamma-satellite sequence where NSs interacts with DNA [167]. Targeting of these sequences by NSs was correlated with the induction of chromosome cohesion and segregation defects in RVFV-infected murine and ovine cells. Such phenomena may be responsible for the foetal deformities and abortions observed in infected animals, in addition to the necrosis of the placentome.

Very recently, a novel function of NSs was described simultaneously by Ikegami et al. [127, 128] and Habjan et al. [109]: NSs promotes post transcriptional downregulation of dsRNA-dependent protein kinase (PKR) and therefore prevents phosphorylation of eIF2 $\alpha$ (eukaryotic initiation factor 2 alpha), phosphorylated eIF2 $\alpha$ being known to lead to suppression of host and viral translation. Virulent RVFV was largely resistant to the antiviral action of PKR because NSs triggers the specific degradation of PKR via the proteasome. Together with the data showing that NSs suppresses cellular transcription, these studies on the downregulation of PKR highlight different strategies of NSs to prevent the innate antiviral host responses.

It was also observed that this activity is specific to RVFV NSs but not shared with other phleboviruses like sandfly fever Sicilian virus or the orthobunyavirus, LaCrosse virus [109]. This conclusion was based on the production of a recombinant ZH548 RVFV in which the NSs sequence was replaced by the heterologous NSs from the phlebovirus or the orthobunyavirus. One should note that, in contrast with the 
PKR degradation activity, the IFN antagonistic activity of NSs is conserved among orthobunyaviruses and phleboviruses [76].

Altogether, it appears that NSs has multiple functions to counteract the host cell interferon response, either at the transcriptional or at the translational levels by degrading PKR, which in turn facilitates translation of the viral products [127].

\subsubsection{The role of the NSm protein as a suppressor of virus-induced apoptosis}

To determine the biological function of NSm1 and NSm2, an M segment-deletion mutant arMP12-del 21-384 was produced in which the first 3 initiating AUG were deleted. This virus was unable to synthesize the two nonstructural NSm proteins. Although its growth was similar to that of the parental virus arMP12, it induced extensive cell death and produced larger plaques than the parent [287]. Further analyses indicated that the deletion mutant triggered apoptosis through the caspase 3,8 and 9 pathway, thus revealing that NSm has an anti-apoptotic function and contributes to pathogenesis. Interestingly, a study on Maguari virus showed that the NSm protein of this orthobunyavirus, which has no sequence homology with the NSm protein of phleboviruses or common coding strategy [148, 202], is not essential for growth in cultured cells [225]. It is not yet known if these NSm proteins from two distantly related viruses from distinct genera (Orthobunyavirus and Phlebovirus) share the same anti-apoptotic function. However, in this case, the same evolutionary pathway could have occurred to conserve the functions of both NSm and NSs among genera.

\section{MOLECULAR EPIDEMIOLOGY}

\subsection{Influence of widespread virus movement, reassortment and introduction across natural barriers on RVFV genomics}

The evolutionary history of RVFV is complex and has been influenced greatly by dramatic changes to the environment throughout
Africa in the past approximately 150 years. Over that time, RVFV gene flow has been influenced on multiple levels ranging from the macroscopic (i.e., geographic dispersal) to the molecular (i.e., reassortment events) $[14,19$, 21, 231-234, 239, 288]. Overall, the virus can be subdivided into at least 7 major genetic lineages (Fig. 3). While no exclusive correlation of virus genotype and geographic location can be observed, representatives from one area do tend to cluster together within each lineage [19]. However, virus strains with distant origins can be found within each of the 7 main lineages, which provide strong evidence of widespread dispersal and movement of RVFV genotypes throughout Africa. Striking examples of the magnitude of this long distance translocation can be found by the monophyletic linkage of isolates from regions as distant as Egypt, Madagascar and Zimbabwe or Kenya, Mauritania, Burkina Faso, Zimbabwe and South Africa (Fig. 3).

There have been at least three separate introductions of RVFV across significant natural geographic barriers. The large 1977-1979 Egyptian "virgin-soil" outbreak marked the first time the virus was recognized north of the Sahara desert and was associated temporally with construction of the Aswan High Dam along the Nile river $[133,183]$. Later, the virus was isolated for the first time outside of continental Africa in 1979 across the Indian Ocean in Madagascar where the virus is now endemic [194-196]. More recently in 2000, the virus was introduced across the Red Sea into Saudi Arabia and Yemen and precipitated outbreaks among livestock and humans [10]. In each of these examples, firm phylogenetic linkages were established between RVFV collected during each outbreak and virus strains circulating a few years earlier within continental Africa [19, 234, 239]. The Arabian Peninsula introduction in 2000 is particularly worrisome, as it appears from the genomic data that the origins of this "virgin-soil" outbreak were closely linked to the large 1997-1998 east African epidemic/epizootic (Fig. 3) [19, 239]. After introduction, the virus likely circulated below the threshold of detection by livestock and public health authorities until favorable climatic conditions in 2000 provided an 


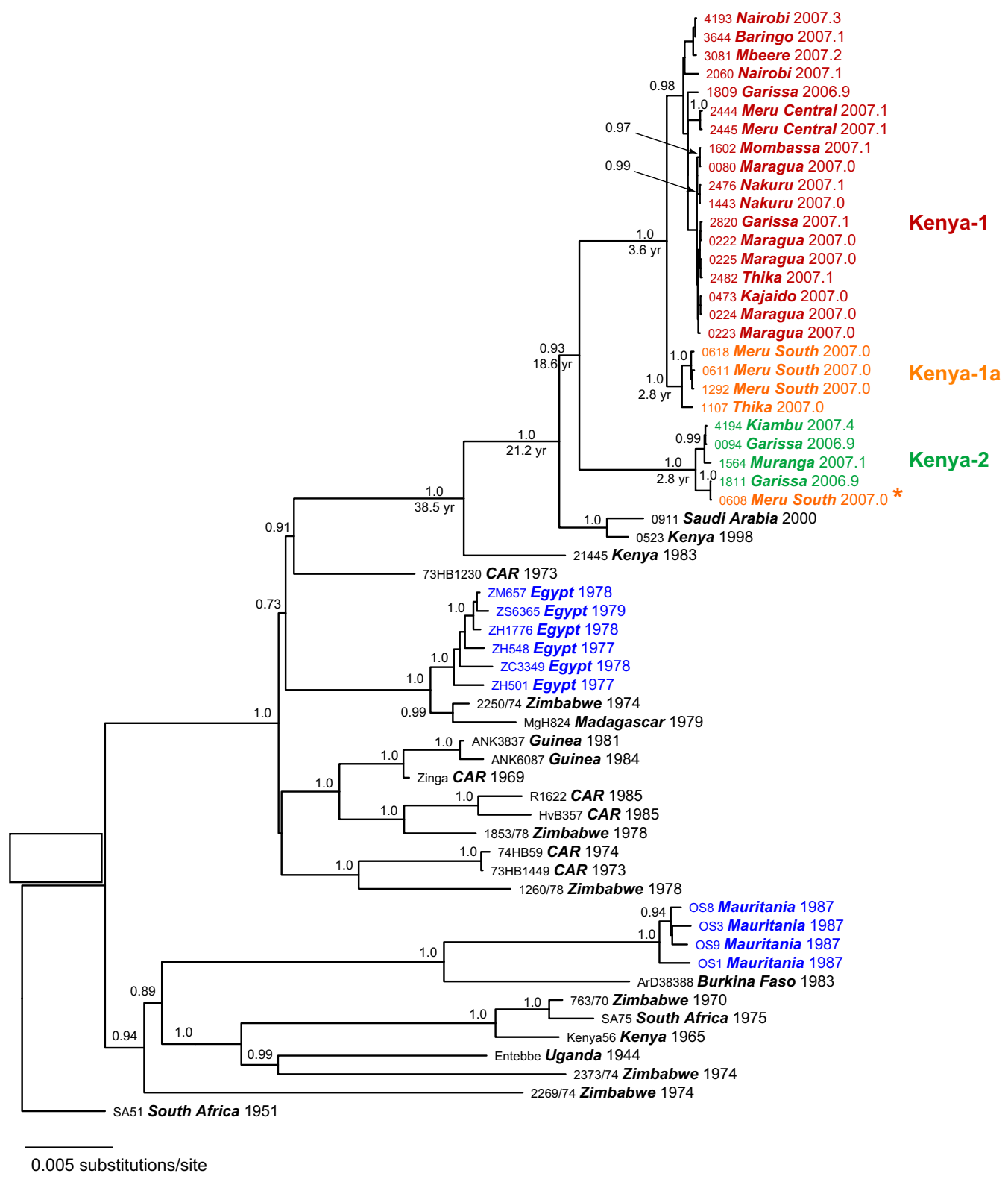

Figure 3. Rift Valley fever virus $M$ segment maximum a posteriori clade credibility tree, MCMC chain length $9.0 \times 10^{7}$ steps, $2.25 \times 10^{6}$ steps $(25 \%)$ removed as burn-in. Posterior support values (highest posterior density, HPD) are indicated as integers (i.e., $100 \%$ support $=1.0$ ) above each node respectively. The calculated mean times to the most recent common ancestor (TMRCA) are indicated below each respective node and are enumerated as years before the collection date of the last outbreak specimen (May, 2007). The 2006-2007 Kenyan outbreak specimen M segment reassortant (strain \#0608) is indicated by an asterisk. Adapted from [21]. (A color version of this figure is available online at www.vetres.org.) 
opportunity for increased virus activity. It is clear that RVFV has crossed several significant physical barriers with impunity in the past and the potential exists for further introductions, especially given ongoing increases in the global movement of humans, livestock and mosquitoes.

Genomic rearrangement via RNA segment reassortment or homologous recombination are both potent mechanisms to promote genetic diversity and can allow for the emergence of novel RVFV strains. The reassortment of RNA genome segments among viruses of the family Bunyaviridae has been reported frequently in both in vitro and in vivo studies $[15,23,28,34$, 102]. Reassortment among RVFV strains has also been well documented [19, 21, 231, 234]. However in sharp contrast, no evidence of homologous recombination among RVFV has been reported [19]. Potential reassortant events have been identified involving each of the three RVF genome segments (i.e., S segment: Lineage $B$ viruses, M segment: Kenya 2006-2007 strain \#0608, L segment: CAR strain 73HB1230) $[21,234]$. The impact of these reassortment events on RVFV replication, fitness and, most importantly, host virulence is not fully known and requires further detailed study.

\subsection{Genomic diversity and molecular evolutionary rate}

A key feature of RVFV genomics is the relatively low genetic diversity: approximately $4 \%$ and $1 \%$ at the nucleotide and protein coding levels, respectively [19, 21, 231, 239]. This low diversity contrasts sharply with other bunyaviruses, including the tick-borne Crimean Congo haemorrhagic fever virus which was found to have approximately $32 \%$ diversity at the nucleotide level $[31,59]$. The low genomic diversity of RVFV suggests that the virus either has a very low tolerance for mutation within its genome (i.e., an inherently slow molecular clock, or a "double-filter" selection mechanism) or alternatively that the extant viruses collectively identified today as RVFV have a relatively recent common ancestor. The molecular evolutionary rates (measured as nucleotide substitutions per site per year) were recently calculated for 60 complete genomes using a relaxed clock Bayesian algorithm [21, 67, 68]. The mean evolutionary rates and $95 \%$ highest posterior probability distributions (shown in parentheses), were $3.9 \times 10^{-4}(2.4$ $\left.5.5 \times 10^{-4}\right), 3.6 \times 10^{-4}\left(2.6-4.6 \times 10^{-4}\right)$ and $2.8 \times 10^{-4}\left(1.8-3.9 \times 10^{-4}\right)$ nucleotide substitutions/site/year for the $\mathrm{S}, \mathrm{M}$ and $\mathrm{L}$ segments, respectively, and were comparable with other arthropod-borne or mammalian host-restricted single-stranded negative-sense RNA viruses $[21,65,132]$.

\subsection{Recent ancestry and the influence of environmental change}

Using the known date of collection for each virus specimen, the molecular evolutionary rate and the overall genomic diversity, it was possible to estimate the number of years prior to the present that the progenitor of the known RVFV was in circulation [67, 68]. Complete genome data from 60 naturally occurring RVFV specimens [19] revealed that the time to the most recent common ancestor (TMRCA) occurred in the recent past, with mean values of the TMRCA coalescing towards 120-130 years before the present, i.e., approximately 1880 1890 . Such a contemporary origin was surprising, but is broadly consistent with the earliest case reports from Kenya in the early 1900s of a disease resembling RVF among animals [253]. During that time, major ecological changes were occurring in eastern and southern Africa, with the establishment of colonial agriculture systems and the importation of large numbers of highly susceptible European breed livestock [110, 163].

Taken together, the TMRCA and veterinary case reports support a hypothesis that at some time between 1850 and 1910, a previously unrecognized arbovirus ancestor of what we now know as RVFV exploited a newly formed ecological niche created by the sudden appearance of large concentrations of susceptible livestock. Since that time, the virus has subsequently established itself throughout large portions of eastern, western and southern Africa. The strong phylogenetic linkage of virus strains from distant locations suggests that, during the intervening years, the movement of 
infected livestock and the natural dispersal of mosquitoes could have allowed the spread of RVFV throughout continental Africa, Madagascar and the Arabian Peninsula.

\subsection{Insights into RVFV molecular epidemiology from the east African 2006-2007 outbreak}

The large 2006-2007 epizootic/epidemic that occurred in Somalia, Kenya and Tanzania provided the first opportunity to conduct a detailed examination of RVFV molecular epidemiology during an outbreak [206]. During the epidemic period, a total of 1062 human cases and 315 fatalities were reported throughout the region, along with dramatic losses to livestock production [285]. As part of the outbreak response, approximately 3250 animals from Kenya (including cattle, sheep, goats, camels and various wildlife species) were tested for RVFV [21]. Of these, 289 (9.2\%, primarily sheep, cattle, goats and African buffalo) were found to be acutely infected with RVFV by RT-PCR, antigen detection and IgM ELISA. The complete sequences of the $\mathrm{S}, \mathrm{M}$ and/or $\mathrm{L}$ genome segments were obtained from a total of 31 virus specimens representing all affected regions of Kenya and spanning the entire known outbreak time period (December 2006 until May 2007).

All 31 virus specimens were monophyletic with a virus specimen (strain 0523) collected during the previous 1997-1998 east African outbreak and clustered with a larger east African lineage of RVFV (Fig. 3). This lineage has been present in Kenya since at least the early $1980 \mathrm{~s}$, as evidenced by monophyletic grouping of the $\mathrm{S}, \mathrm{M}$ and $\mathrm{L}$ segments (with $100 \%$ support) with a RVFV (strain 21445) collected in 1983. Among the 2006-2007 viruses analyzed, two separate and highly supported sub-lineages (Kenya-1 and Kenya-2) were observed (Fig. 3). In contrast with more limited data from previous outbreaks, there was increased genomic diversity $(\sim 1.6 \%$ at the nucleotide level) relative to that observed among RVFV collected during the Egyptian 1977-1979 (0.3\%) and Mauritanian 1987 $(0.3 \%)$ outbreaks (Tab. I). This finding was unexpected and may reflect differences in the ecological/epidemiological factors that initiated each outbreak. The 2006-2007 Kenya outbreak occurred in a known endemic area, whereas the Egyptian and Mauritanian outbreaks likely resulted from limited or single introductions of RVFV onto "virgin-soil".

While the shared evolutionary history of the 1997-1998 and 2006-2007 outbreak viruses was apparently based on phylogeny, the TMRCA of the Kenya- 1 and Kenya- 2 lineages detected in 2006-2007 was found to be shortly before or during the previous 1997-1998 outbreak (Fig. 3). Surprisingly, further population genetics-based approaches revealed that the recent evolutionary history of the Kenya- 1 and Kenya-2 lineages differed. Both lineages were more closely related to the 1997-1998 RVFV prototype than to each other, indicating ongoing and separate evolutionary patterns since the previous outbreak (Fig. 4). More detailed population genetics analyses revealed that the Kenya-1 lineage viruses had recently undergone demographic or spatial expansion, whereas the Kenya-2 lineage viruses had likely not (Fig. 4) [21]. Interestingly, the timing of the Kenya-1 expansion event was calculated to have occurred a few (2.1-3.7) years prior to the detection of the 2006-2007 outbreak event (Fig. 3). These population genetics-based estimates were found to correlate closely with data from climate models that incorporate normalized difference vegetation imaging that indicated the potential for enhanced RVFV activity risk during that time period $^{2}$. Taken together, these results suggest that an undetected and significant demographic and spatial expansion of the Kenya-1 lineage occurred during the intervening years between the 1997-1998 and 2006-2007 outbreaks. These differing evolutionary patterns are consistent with potentially important biological differences in reproductive fitness existing between local subpopulations of virus within the natural environment.

During this outbreak, human and veterinary epidemiologic data revealed an apparent temporal course of virus activity shifting from the north-east border of Kenya towards the southwest and extending into Tanzania. At that time,

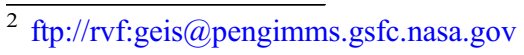


Table I. Comparison of M segment nucleotide (NT) diversity among RVFV collected during enzootic/ endemic and epizootic/epidemic time periods.

\begin{tabular}{lccc}
\hline Country of origin & Date of collection & Virus activity & \% nt difference \\
\hline Zimbabwe & $1970-1978$ & Endemic & 4.7 \\
Central African Republic & $1973-1974$ & Endemic & 1.8 \\
Egypt & $1977-1979$ & Epidemic & 0.3 \\
Mauritania & 1987 & Epidemic & 0.3 \\
Kenya & $2006-2007$ & Epidemic & 1.6 \\
\hline
\end{tabular}

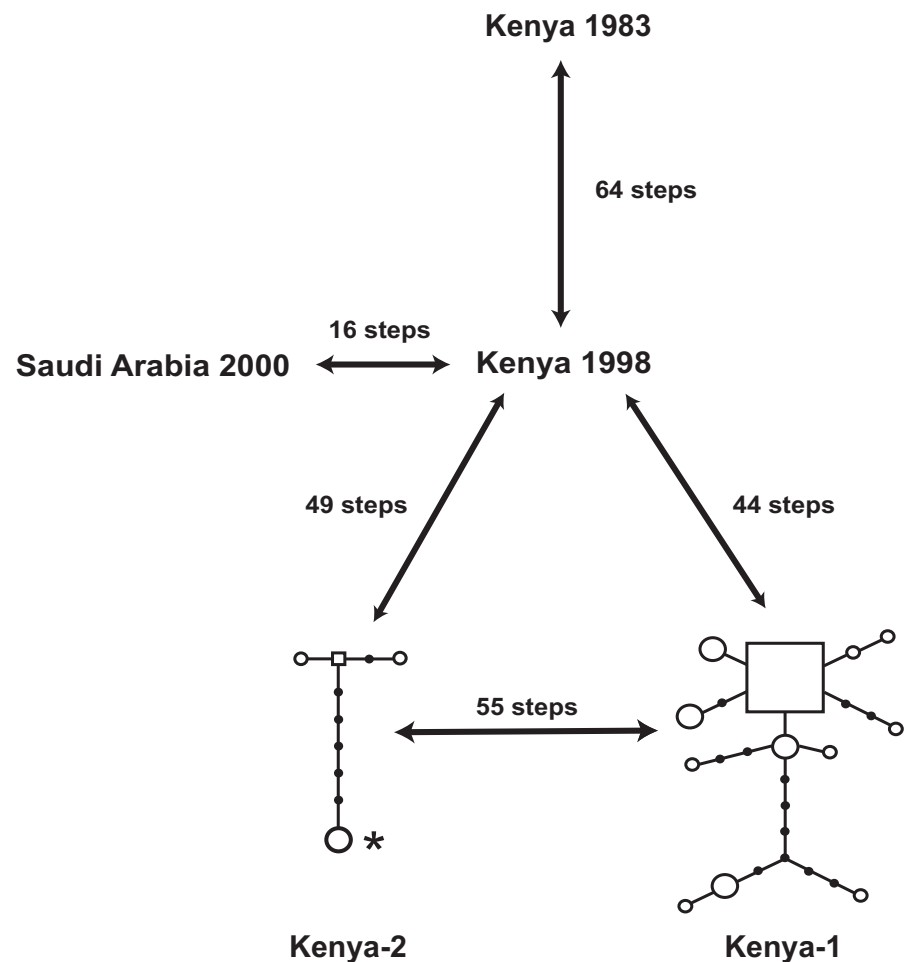

Figure 4. Minimum spanning networks (MSN) visually describing discrete genetic distance between unique haplotypes of the RVFV M genome segment within the greater east African lineage. Each node represents one nucleotide difference between extant (open circle) or inferred (black filled circle) haplotypes. Proportionally larger open circles or squares represent the relative number of extant haplotypes represented in the network. Generally, squares denote the predicted progenitor haplotype for each lineage, whereas circles indicate progeny haplotypes. Note the greater distance as measured in nucleotide changes (steps) between the Kenya-1 and Kenya-2 lineages than with the prototype Kenyan 1997-1998 RVFV strain. Also note the star-like phylogeny of the Kenya-1 lineage indicating the potential for increases in virus population size or geographic range. An asterisk indicates the relative position of the putative $\mathrm{M}$ segment reassortant virus (strain \#0608). Adapted from [21]. 
it was unclear whether this shift was due to initial virus emergence in the north-east followed by direct "wave-like" spread of the virus via livestock or mosquito translocation or, rather, due to changes in rainfall patterns throughout the region, allowing for the eruption of local enzootic foci of virus activity. Among the 31 virus specimens analyzed, no significant evidence could be detected of a correlation between genotype, time of collection, or geographic origin [21]. This suggests that changes in rainfall patterns were more likely responsible for the apparent shift in activity rather than "wave-like" spread throughout the region.

The 2006-2007 data provide a unique basis for understanding the complex interplay between the environment, virus and susceptible hosts that allows for the establishment of RVFV endemicity and to precipitate outbreaks. It is clear that within the Kenyan ecosystem particular virus lineages can contribute to multiple periodic outbreak events over relatively long time periods. Although widespread and explosive RVFV outbreaks are hallmarks of the virus life cycle, the importance of a cryptic enzootic transmission cycle cannot be overstated and requires further study.

\section{PATHOGENESIS AND IMMUNE RESPONSES}

\subsection{Natural infection in animals and humans}

The natural disease has been well described in susceptible animals and particularly in ruminants since the first identification of RVFV in the Rift Valley of Kenya during an epizootic in 1930 [51, 52]. Numerous and well documented descriptions of the symptoms in naturally-infected animals have been recorded [42, 43, 253] and, consequently, detailed descriptions of the natural disease have not been conducted during more recent epizootics. Instead, the most recent descriptions of RVF epizootics have focused on the analytical and predictive epidemiology of the disease [38-40, 168, 169, 272]. A clear distinction can be made regarding the susceptibility to, and progression of the disease in young animals when compared with adults. The basis for these observed differences has not received clear explanation but might be driven by age-related susceptibility of the primary target cells of the virus that allows for more intense viral replication during early infection. Alternatively, differences in the underlying mechanisms of innate immunity that are stimulated by infection, as has been demonstrated with other infectious pathogens and disease models, may exacerbate susceptibility of young animals to RVFV [294].

The classical hallmark of RVF epizootics is the large number of near simultaneous abortions among pregnant ruminants, regardless of the stage of pregnancy. These massive abortion events have been referred to as "abortion storms" and allow for the differentiation of RVF from many of the other common infectious causes of abortion in ruminants such as: Q fever (Coxiella burnettii), chlamydiosis, salmonellosis, listeriosis or toxoplasmosis. In non-endemic countries, an active surveillance strategy employing the use of sentinel herds is cost prohibitive. However, robust passive surveillance-based systems that rely on the detection and rapid reporting of significant abortion events to national authorities (e.g., $>20 \%$ of pregnant animals in a herd suddenly aborting with accompanying signs of jaundice among survivors) could provide a cost effective means to detect the emergence of this significant veterinary and human health threat.

RVFV infection of animals can occur by the bite of an infected mosquito or by direct contact with infected animal tissues, bodily fluids and fomites, particularly if associated with abortions. Aborted foetal materials and placental membranes contain large numbers of virus particles which can either contaminate the local environment directly or infect animals in close contact. The RVFV may persist for relatively long periods in the environment as has been demonstrated during in vitro experiments [9, 49, 257].

The relative importance of each mode of transmission varies according to the stage of the epizootic: in the first stage, the bites of infected mosquitoes are the predominant mode of transmission whereas direct contact of animals with infected tissues (foetal or otherwise) 
may become predominant during the amplification stage of the epizootic [191]. The relative importance of each mode of transmission still remains a bit controversial as some authors argue that the bites of infected mosquitoes constitute the main means of transmission of the virus, whatever the circumstances and even during a large outbreak [22, 25]. Exposure to infected tissues or bodily fluids constitutes the main route of infection for humans [253]. Transmission via infected mosquitoes remains important for the dissemination of RVFV between herds or flocks over short distances but also allows for the emergence and dissemination of the disease over longer distances, throughout a region or a country, but has to be preceded by the movement of infected animals [36] or by translocation of infected mosquitoes. Mosquito-borne transmission is also the most important mode during an enzootic cycle, i.e., without any clear signs of the disease but with an active circulation of the virus between susceptible animals.

The mechanisms and epidemiological importance of virus shedding from mammalian hosts is also a subject of debate. It is clear that the infectivity of blood during acute infection is high, with extremely high titres of virus up to $10^{8.5}$ mouse $\mathrm{LD}_{50}$ per $0.02 \mathrm{~mL}$ of blood at the peak of viraemia in sheep [173]). Aborted materials constitute another route of virus transmission, through direct contact with foetal envelopes, placenta and the foetus. Virus within these tissues may stay infectious over a period of a few days as RVFV particles are rather resistant to inactivation when in a protein-rich environment. In contrast, other sources of virus like nasal and lacrymal secretions have been suggested but not confirmed in controlled laboratory studies [274, 275]. The shedding of RVFV into milk has potentially large consequences for public health. The consumption of raw milk, such as during the small epidemic in Mayotte [242], is often reported as a potential risk factor for exposure to the virus. The probability for presence of the virus in milk during the viraemic phase has been confirmed experimentally but in later stages of infection, the presence of virus in milk is questionable and, if it exists, the viral load would be low $[70,71]$. To date, the presence of RVFV in the faeces or urine of infected animals has not been demonstrated, except when contaminated by frank blood.

In humans, detailed studies of RVFV infection were completed during several of the more recent epidemics that occurred in the Arabian Peninsula and in Africa. These recent outbreaks have provided an opportunity to examine confirmed RVF cases and investigate associated disease symptoms more precisely. In the vast majority of cases, infection with RVFV was asymptomatic. For the small proportion with clinical signs, the majority presented with an influenza-like syndrome without any severe sequelae. However, RVFV epidemics can involve hundreds if not thousands of individuals. The manifestation of severe RVF disease in humans is variable. Humans may develop a wide range of clinical signs including hepatitis, retinitis, delayed-onset encephalitis and, in the most severe cases, haemorrhagic disease. The overall case fatality ratio is estimated to be between $0.5 \%$ and $2 \%$. Human cases with jaundice, neurological disease, or haemorrhagic complications are at increased risk of fatality $[149,164]$. A summary of the frequency and clinical characteristics of a RVF epidemic that occurred in Saudi Arabia in 2000-2001 [11] in 683 patients [164] can be found in Table II. It is worthwhile to note that, in contrast to the massive abortion storms and extremely high fatality observed among young ruminant animals during epizootics, human children, pregnant women and neonatal infants seem to have been spared the disease. During the 2000-2001 RVF outbreak in the Arabian Peninsula, no child under the age of 10 years old was confirmed to have died as a result of RVFV infection. The underlying difference in susceptibility of young and pregnant animals with that observed in humans requires further study and raises an important question: are the dramatic differences in lethality the result of a lack of contact of children with infected mosquitoes or infected animals or are there true differences in susceptibility between young animals and young children? 
Table II. Clinical features of 683 patients with laboratory-confirmed RVF in Saudi Arabia in 2000-2001 (adapted from [164]).

\begin{tabular}{lc}
\hline Variable & $n^{\mathrm{a}} / N^{\mathrm{b}}(\%)$ \\
\hline Fever & $499 / 539(92.6)$ \\
Nausea & $315 / 530(59.4)$ \\
Vomiting & $280 / 532(52.6)$ \\
Abdominal pain & $202 / 532(38.0)$ \\
Diarrhea & $118 / 530(22.1)$ \\
Jaundice & $96 / 530(18.1)$ \\
CNS manifestations & $81 / 475(17.1)$ \\
(confusion, lethargy, & \\
disorientation, vertigo, coma, & \\
tremor, convulsions, ...) & \\
Haemorrhagic manifestations & \\
(haematemesis, petechiae, bleeding, & \\
purpura, gingival bleeding, & \\
epistaxis, ..) & \\
Ocular complications & \\
(vision loss, scotomas, ...) & \\
Deaths & $95 / 694(7.1)$ \\
\hline a $n=$ Number of patients with symptom. \\
b $N=$ Number of patients under active observation.
\end{tabular}

\subsection{Lessons from animals models of RVF}

Animal models of RVFV infection are important for reproducing natural infection in a controlled manner. These models have concerned various target and non-target animal species: ruminants (sheep, goats and cattle), laboratory animals (mice, rats and hamsters) and non human primates [22].

The incubation period following infection, ranges from a few hours to a few days and is dependent on multiple factors, including: the inoculation dose, the virus strain, the route of inoculation, the age of each animal and the animal species tested. When clinical signs do appear, there is a marked febrile response that may be very high $\left(>42{ }^{\circ} \mathrm{C}\right)$ and may last for 3 days (ranging from 0 to 5 days). During acute infection, the viraemic phase is another almost constant feature of experimental RVFV infection, but may vary in intensity and duration according to the inoculated dose, the virus strain and the degree of natural susceptibility of the infected animals. Depending on the host's innate susceptibility or resistance, experimental infections often result in three scenarios [41, 56, 189, 198, 259, 289]:

- Scenario 1: Severe acute lethal infection. In this scenario the viraemia is uncontrolled, remains high and the infected animal dies rapidly. A clear relationship has been demonstrated between the viral load in blood (as assessed by real time RT-PCR or LAMP) - for loop-mediated isothermal amplification-PCR; see Section 6: "Old and new diagnostic tools for RVF" - and the final prognosis and outcome of infection $[18,152,210,223]$ in humans and in livestock. In these studies, humans with a high virus load at the time of presentation at hospital were found to be significantly associated with fatal outcome.

- Scenario 2: Mild to asymptomatic infection. The viraemia decreases rapidly, if present at all, and the infected animals recover their initial status without any long term sequelae.

- Scenario 3: Delayed onset complications of infection. After the first phase with fever and viraemia, a second phase can occur with an additional febrile phase and viraemia that may be the result of secondary dissemination of virus into other organs, particularly in the central nervous system, after crossing the blood-brain barrier, and in the retina, leading to a delayed onset of symptoms that are often associated with severe, long term consequences, including blindness, ataxia and potential fatalities.

The patterns observed during experimental infection of animals are similar to those reported for natural infections of animals and humans. In both natural and experimental infections, consistent elevations of liver enzymes and decreases in total leukocyte counts are associated with severe disease.

In both animals and humans, the primary site of RVFV-induced lesions is the liver. This finding is consistent among severe cases and has 
been clearly demonstrated by histopathological examination of tissues of experimentallyinfected sheep [44, 45]. The rapid onset of severe hepatic damage, particularly in ruminants, may explain many of the early clinical signs associated with severe RVF disease. Although RVFV is primarily hepatotropic, during severe infections the virus can be found in virtually all tissues and cell types [78], indicating that the as yet undiscovered cellular receptor is likely to be ubiquitous. In the absence of an efficient innate response (due to the mechanisms used by the virus for blocking the production of host-cell antiviral proteins induced by type I interferons via the NSs gene product; see previous Subsection 2.3: "The nonstructural proteins and their role in evasion of the innate immune response"), the virus causes marked cytopathic effect very rapidly following infection of the primary target cells, leading to multifocal to coalescing zones of hepatic necrosis with inflammatory infiltrates of immune effector cells. The finding of widespread hepatic necrosis is a classic hallmark of severe RVFV disease both in experimental $[43,44]$ and natural infections [78].

The primary tropism for the liver, after the presumed initial uptake of virions by immune system sentinel cells, may be altered when an aerosol route of exposure is employed. While not a typical route of exposure, this mode of infection has been described among slaughterhouse and laboratory workers [1, 33, 246]. In mice experimentally infected after inhalation of infectious aerosols, the lungs became the primary site of replication without any clear signs of pneumonia. However, after $48 \mathrm{~h}$ following experimental aerosol infection, the virus was isolated from the livers of infected mice that died as a result of a fulminant hepatitis associated, as already described, with a massive hepatic necrosis [29].

While infection via the oral mucosal surfaces has been documented [71, 72], attempts to infect lambs, kittens and puppies with RVFVcontaminated milk were not successful [141]. Infection of lambs via the intestinal tract by ingestion of RVFV-containing gelatin capsules was also unsuccessful but is a possible route of infection. However, the acidity of the stom- ach lumen is deleterious for RVFV, which is very susceptible to inactivation in solutions with a $\mathrm{pH}$ of less than $6.8[143,186]$.

Some animal models, particularly inbred strains of rats, have very striking differences in susceptibility to RVFV infection [4, 221]. These differences are not simply limited to differences between lineages of inbred strains but also depend on the commercial breeding source used in these studies [228]. As an example, Wistar-Furth (WF) rats were found to be very susceptible to experimental RVFV infection and Lewis (LEW) rats were resistant in one laboratory $[6,8,221]$; in another experiment using rats from an European breeding colony (mol), $\mathrm{LEW} / \mathrm{mol}$ rats developed acute hepatitis and died after infection, whereas WF/mol rats survived the infection [228]. Genetic differences in susceptibility to RVFV infection, such as those observed in experimental infections of inbred rats, may explain in part the conflicting susceptibilities seen among different breeds of sheep under field conditions [80], although these results were not reproduced during controlled experimental infections [211, 259]). Previous experiments with back crosses of inbred rat strains suggest that the number of genes governing these susceptibility differences in the rat may be low [220] and suggests that it may be possible to select for resistant domestic animals through controlled breeding programs.

\subsection{Immune responses}

A robust innate immune response is critical for control of the initial phase of virus dissemination and eventual animal survival. A vigorous adaptive immune response is developed rapidly following infection, with the production of detectable neutralizing antibodies from the 4th-8th day after infection [117, 188, 193, 216]. These antibodies, which are primarily directed against the viral glycoproteins, $G_{n}$ and $\mathrm{G}_{\mathrm{c}}$, are also accompanied by the production of $\operatorname{IgM}$ and $\operatorname{IgG}$ antibodies raised against the nucleoprotein, $\mathrm{N}$, and the nonstructural protein, NSs [171]. The N nucleoprotein is the major immunogen in bunyavirus infection [79, 130] and represents the complement fixing antigen. While the titers of antibodies against the $\mathrm{N}$ 


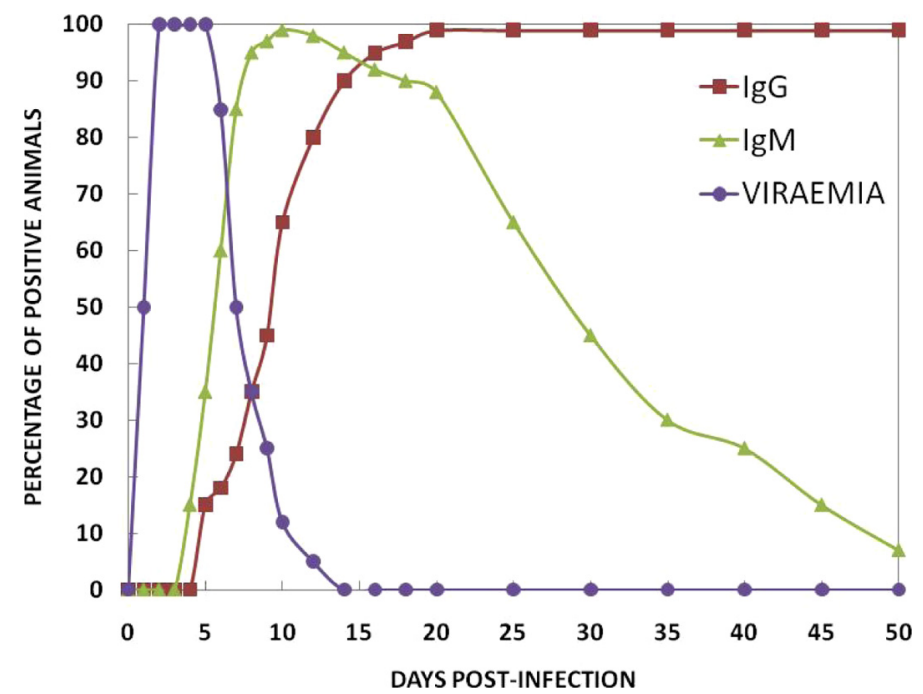

Figure 5. Schematic representation of time course of viraemia and antibody responses against RVFV in experimentally-infected animals. (A color version of this figure is available online at www.vetres.org.)

nucleoprotein are often quite high, the level of antibodies against the NSs protein is typically rather lower. The measurement of anti-N and anti-NSs antibodies can allow a DIVA (differentiation of infected and vaccinated animals) test to be developed as the animals vaccinated with an inactivated or a recombinant live attenuated vaccine such as the candidate clone 13 or one similar to those reported in Bird et al. [22] (which contained partial or complete deletions of the NSs gene $[20,201,271]$ ) do not produce antibodies against NSs [171] (see also Section 6: "Old and new diagnostic tools for RVF"). The titration of IgM antibodies is critical for detection of acute infections and can be coupled with the results of molecular (RT-PCR) and IgG detection assays to accurately stage the time since infection as IgM antibodies do not persist beyond the 50th day in the majority of cases after infection [209, 213]. However, important individual variation in IgM persistence has been demonstrated in cattle where IgM antibodies may persist for 5 months, so individual animal results must be evaluated within this context [197]. By combining virus isolation in cell culture or molecular detection of viral RNA with $\operatorname{IgM}$ and $\operatorname{IgG}$ antibody assays, it is possible to determine the stage of infection quite precisely (see Fig. 5). The neutralizing antibodies are the key factor for the initial and persistent protection of infected animals [222] and are, consequently, a good correlate of the protection induced by vaccines against RVFV: if vaccinated animals produce a high level of neutralizing antibodies, they will very likely be protected against experimental challenge or subsequent natural viral infection under field conditions [73].

Deep knowledge regarding RVFV immunology is lacking and requires further detailed studies of both the innate, humoral and cellmediated immune pathways.

\section{VECTORS OF RVFV}

RVFV has the potential to infect a remarkable array of vectors, including ticks and a variety of flies $[53,55,88,146,153,157,158,184$, 268], unlike the majority of arboviruses which tend to be adapted to a narrow range of vectors $[35,60,137,166,180,187,279,283]$. The propensity of the virus to develop significant viraemia in sheep, goats and cattle and to adapt to anthropogenic alteration of the environment, from development of irrigation schemes for 
agriculture (and subsequent concentration of mosquito vectors) to intensive farming with livestock, may be responsible for this adaptability. Vectors of RVFV can be classified into "reservoir/maintenance" vectors, including certain Aedes species (spp.) mosquitoes (Diptera: Culicidae) associated with freshly flooded temporary $[86,87]$ or semi-permanent fresh-water bodies [98], and "epidemic/amplifying" vectors, consisting of Culex spp. associated with more permanent fresh-water bodies [178].

Tables III and IV list those species from which RVFV has been isolated in the wild, which have also been shown to be susceptible to and capable of transmitting RVFV in the laboratory. The minimum infection rates (MIR), based on the numbers of isolations per 1000 adult female mosquitoes, support the epidemiological importance of Aedes (Neomelaniconion) mcintoshi (Huang, 1987), Aedes (Aedimorphus) vexans subspecies arabiensis (Patton, 1905), Aedes (Aedimorphus) dentatus (Theobald, 1904), Culex (Culex) theileri (Theobald, 1903) and Culex (Culex) poicilipes (Theobald, 1903) as RVFV vectors. The vector competence index (VCI) [136] allows for combining infection and transmission rates into a single statistic for comparing the experimental vector competence of vectors. This statistic illustrates the importance of the usual RVFV vectors, except for Ae. mcintosh $i$, the most important maintenance vector of RVFV in east and southern Africa. However, isolation, infection and transmission rates alone are not always sufficient to determine vector capability. Abundance, longevity, distribution and feeding behaviour are all important facets of what constitutes a good vector, as are inherent capabilities such as threshold susceptibility to infective virus. This is illustrated with $C x$. pipiens, the RVFV vector responsible for the extensive 1977 Egyptian outbreak [115, 182]. Values of the MIR (Tab. III) are consistently low for this species. However, the VCI range from low to extremely high (Tab. IV) for the various experiments. A striking feature of Table IV is the range of IR, TR and VCI for Cx. pipiens and Culex (Culex) antennatus (Becker, 1903), the significance of which is not readily obvious. The Egyptian $C x$. pipiens involved in transmission of RVFV is almost certainly of the variety molestus, an unusually anthropophilic, endophilic form of the normally ornithophilic, exophilic type species. To complicate things further, Culex (Culex) quinquefasciatus (Say, 1823), which is morphologically similar to Cx. pipiens and behaviourally similar to $C x$. pipiens var. molestus, also occurs in this area. The presence of all three taxa in Egypt, the source of the mosquitoes used in the vector competence experiments, may be responsible for these disparate results but this has yet to be demonstrated. Gargan et al. [94] demonstrated that degree of colonization of experimental $C x$. pipiens had a significant effect on infection and transmission rates, with infection rates increasing (possibly due to artificial selection of more susceptible individuals) and transmission rates decreasing on average. Filial (F) generations of $C x$. pipiens in the published experiments ranged from $F_{2}$ [177] to $F_{67}$ [261]. The one thing the three members of $C x$. pipiens sensu lato do have in common is widespread and abundant association with the settlements and irrigation canals along the banks of the Nile River and in its delta, in close association with humans and livestock and ideally situated to act as vectors.

Transmission of RVFV was associated primarily with a limited number of mosquito species prior to 1987 , even though it had been isolated from a much wider range of arthropods, including Simulium spp. blackflies (Diptera: Simuliidae) [268], Culicoides spp. midges (Diptera: Ceratopogonidae) [55, 153] and Amblyomma variegatum ticks (Acari: Ixodidae) [88]. Experimental susceptibility and transmission studies extended the range of potential vectors to include Phlebotomus spp. sandflies (Diptera: Psychodidae) [64, 263], Rhipicephalus appendiculatus ticks [52] and a host of mosquito species [91, 96, 135, 176, 260, 261, 264]. However, the recognized vectors responsible for maintenance and amplification of RVFV included members of the subgenera Neomelaniconion of Aedes and Culex of Culex [98, 135, 144, 158, 172, 176, 179].

Member species of the mosquito genera, Anopheles, Eretmapodites, Coquillettidia and Mansonia have been implicated as vectors after isolations of RVFV had been obtained from 
Table III. Minimum infection rates (MIR) for Rift Valley fever virus in adult female mosquitoes sampled in the wild.

\begin{tabular}{|c|c|c|c|c|}
\hline \multirow[t]{2}{*}{ Species } & \multicolumn{4}{|c|}{ Field isolations } \\
\hline & Locality & Sample size & $\mathrm{MIR} / 1000$ & References \\
\hline Ae. (Adm.) dentatus & Zimbabwe 1969 & 23 & 43.5 & {$[172]$} \\
\hline \multirow[t]{3}{*}{ Ae. (Adm.) vexans arabiensis } & Senegal 1991-1996 & 42055 & 0.2 & {$[88]$} \\
\hline & Saudi Arabia 2000 & 8091 & 0.9 & {$[138]$} \\
\hline & Saudi Arabia 2000 & 122 & 8.2 & [185] \\
\hline \multirow[t]{3}{*}{ Ae. (Neo.) circumluteolus } & South Africa 1955 & 4657 & 0.4 & [144] \\
\hline & Uganda 1955 & 1508 & 0.7 & [282] \\
\hline & South Africa $1981^{*}$ & 695 & 1.4 & {$[134]$} \\
\hline \multirow[t]{4}{*}{ Ae. (Neo.) mcintoshi } & Kenya 1981-1984 & 59644 & 0.2 & {$[157]$} \\
\hline & Kenya 1978-1979 & 12 & 83.3 & {$[55]$} \\
\hline & Zimbabwe 1969 & 3842 & 0.5 & {$[172]$} \\
\hline & South Africa 1974-1975 & 1315 & 1.5 & {$[176]$} \\
\hline Ae. (Neo.) palpalis grp.** & Central African Republic 1969 & 795 & 1.3 & {$[63]$} \\
\hline \multirow[t]{4}{*}{ Cx. (Cux.) antennatus } & Nigeria $1967-1970$ & unrecorded & $(1)^{* * *}$ & [153] \\
\hline & Kenya 1989 & 250 & 0 & {$[160]$} \\
\hline & Kenya 1981-1984 & 4988 & 0.6 & [157] \\
\hline & Egypt 1977 & 121 & 0 & [182] \\
\hline Cx. (Cux.) neavei & South Africa 1981 & 1953 & 0.5 & [179] \\
\hline \multirow[t]{5}{*}{ Cx. (Cux.) pipiens } & Egypt $1977-1978$ & 39150 & 0.03 & {$[115]$} \\
\hline & Egypt 1977 & 52629 & 0.04 & {$[182]$} \\
\hline & Kenya 1989 & 4987 & 0 & [157] \\
\hline & South Africa 1970 & 4833 & 0 & {$[172]$} \\
\hline & South Africa 1981 & 63 & 0 & [179] \\
\hline \multirow{2}{*}{ Cx. (Cux.) poicilipes } & Senegal 1998-1999 & 24327 & 1.5 & {$[62]$} \\
\hline & Mauritania 1998-1999 & 4691 & 5.8 & {$[62]$} \\
\hline \multirow[t]{6}{*}{ Cx. (Cux.) theileri } & South Africa 1953 & unrecorded & $(2)^{* * *}$ & {$[98]$} \\
\hline & South Africa 1956 & unrecorded & $(2)^{* * *}$ & {$[176]$} \\
\hline & Zimbabwe 1969 & 103 & 9.7 & {$[172]$} \\
\hline & South Africa 1970 & 1398 & 2.9 & [172] \\
\hline & South Africa 1970 & 144 & 6.9 & {$[172]$} \\
\hline & South Africa 1974-1975 & 12738 & 0.9 & {$[176]$} \\
\hline Cx. (Cux.) tritaeniorhynchus & Saudi Arabia 2000 & 15428 & 0.4 & [138] \\
\hline \multirow[t]{4}{*}{ Cx. (Cux.) zombaensis } & South Africa 1981 & 6621 & 1.1 & [179] \\
\hline & Kenya 1981-1984 & 2326 & 0.4 & [157] \\
\hline & Zimbabwe 1978 & 24 & 0 & [254] \\
\hline & Kenya 1989 & 18828 & 0.3 & {$[157]$} \\
\hline Er. chrysogaster s.1./Er. spp.**** & Uganda 1944 & 1865 & 1.6 & [243] \\
\hline \multirow{2}{*}{ Er. quinquevittatus } & South Africa 1971 & 423 & 2.4 & {$[172]$} \\
\hline & Kenya 1981-1984 & 2660 & 0 & {$[157]$} \\
\hline \multirow[t]{3}{*}{ Oc. (Och.) juppi } & South Africa 1984 & 5425 & 0 & {$[96]$} \\
\hline & South Africa 1974-1975 & 2945 & 1.0 & {$[176]$} \\
\hline & South Africa 1987 & 656 & 0 & [135] \\
\hline
\end{tabular}

${ }^{*}$ Mostly Ae. circumluteolus with only a few Ae. Luteolateralis.

** Ae. palpalis grp. = jamoti $62 \%$ : crassiforceps $21 \%$ : carteri $7 \%$ : bolensis/palpalis $10 \%$.

${ }^{* * * *}$ Number of isolates; undisclosed sample size.

${ }^{* * * * *}$ Er. chrysogaster s.1. (chrysogaster/semisimplicipes/grahami/intermedius/mahaffyi/haddowi/harperi/gilletti) 75\%: inornatus/penicillatus $14 \%$ : dracaenae ssp. ferox $11 \%$ : leucopus ssp. productus $<1 \%$. 
Table IV. Experimental infection rate (IR), transmission rate (TR) and vector competence index (VCI) for Rift Valley fever virus in mosquito species from which RVFV has been isolated in the wild.

\begin{tabular}{|c|c|c|c|c|c|}
\hline \multirow[t]{2}{*}{ Species } & \multicolumn{5}{|c|}{ Lab experiments } \\
\hline & Origins & $\mathrm{IR} / \%\left(n^{*}\right)$ & $\mathrm{TR} / \%(n)$ & References & $\mathrm{VCI} * *$ \\
\hline Ae. (Adm.) dentatus & South Africa & $87(39)$ & $35(34)$ & {$[135]$} & 0.31 \\
\hline Ae. (Adm.) vexans arabiensis & Saudi Arabia & positive (15) & $1 / 1$ pool & {$[138]$} & \\
\hline \multirow[t]{3}{*}{ Ae. (Neo.) circumluteolus } & South Africa & $83(69)$ & $34(53)$ & {$[179]$} & 0.28 \\
\hline & South Africa & $29(63)$ & $0(4)$ & {$[174]$} & \\
\hline & Kenya & $76(42)$ & $18(17)$ & {$[267]$} & 0.13 \\
\hline \multirow[t]{3}{*}{ Ae. (Neo.) mcintoshi } & South Africa & $39(85)$ & $17(6)$ & {$[176]$} & 0.06 \\
\hline & Zimbabwe & $43(7)$ & $0(2)$ & {$[174]$} & \\
\hline & Kenya & $50(355)$ & $12(97)$ & {$[267]$} & 0.06 \\
\hline Ae. (Neo.) palpalis & Central Africa Republic & $86(169)$ & $54(26)$ & {$[267]$} & 0.46 \\
\hline \multirow[t]{3}{*}{ Cx. (Cux.) antennatus } & Egypt & $84(25)$ & $38(16)$ & [91] & 0.32 \\
\hline & Kenya & $60(135)$ & $60(5)$ & {$[267]$} & 0.36 \\
\hline & Egypt & $92(48)$ & $7(30)$ & {$[264]$} & 0.06 \\
\hline Cx. (Cux.) neavei & South Africa & $67(61)$ & $14(22)$ & {$[174]$} & 0.09 \\
\hline \multirow{5}{*}{ Cx. (Cux.) pipiens } & Egypt & positive (100) & $4 / 4$ pools & [115] & \\
\hline & Egypt & $87(15)$ & $40(15)$ & [182] & 0.35 \\
\hline & Egypt & $97(143)$ & $33(118)$ & {$[81]$} & 0.32 \\
\hline & Egypt & $91(64)$ & $100(8)$ & {$[267]$} & 0.91 \\
\hline & Egypt & $74(346)$ & $7(102)$ & [264] & 0.05 \\
\hline \multirow[t]{2}{*}{ Cx. (Cux.) poicilipes } & South Africa & $90(29)$ & $15(26)$ & {$[135]$} & 0.14 \\
\hline & Egypt & $56(9)$ & & {$[264]$} & \\
\hline \multirow[t]{3}{*}{ Cx. (Cux.) theileri } & South Africa & $96(93)$ & $55(20)$ & {$[174]$} & 0.53 \\
\hline & South Africa & $94(68)$ & $56(18)$ & {$[178]$} & 0.52 \\
\hline & South Africa & $83(192)$ & $27(67)$ & [176] & 0.22 \\
\hline$C x$. (Cux.) tritaeniorhynchus & Saudi Arabia & $73(40)$ & $17(36)$ & {$[138]$} & 0.12 \\
\hline \multirow[t]{3}{*}{ Cx. (Cux.) zombaensis } & South Africa & 73 (192) & $23(106)$ & [179] & 0.17 \\
\hline & Zimbabwe & $75(24)$ & $40(5)$ & {$[174]$} & 0.30 \\
\hline & Kenya & $71(72)$ & $16(61)$ & {$[265]$} & 0.12 \\
\hline Er. chrysogaster/intermedius ${ }^{* * *}$ & Uganda & $78(92)$ & $4(92)$ & [245] & 0.03 \\
\hline Er. quinquevittatus & South Africa & $75(146)$ & $5(22)$ & {$[174,176]$} & 0.03 \\
\hline Oc. (Och.) caballus & South Africa & $32(245)$ & $0(27)$ & {$[176]$} & \\
\hline Oc. (Och.) caballus/juppi ${ }^{* * * *}$ & South Africa & & $33(3)$ & [98] & \\
\hline \multirow[t]{3}{*}{ Oc. (Och.) juppi } & South Africa & $50(12)$ & $0(3)$ & {$[96]$} & \\
\hline & South Africa & $49(143)$ & $5(16)$ & {$[176]$} & 0.03 \\
\hline & South Africa & $22(23)$ & $0(2)$ & {$[176]$} & \\
\hline
\end{tabular}

${ }^{*} n=$ Sample size.

${ }^{* *} \mathrm{VCI}=\mathrm{IR} \times \mathrm{TR}$, with a maximum value of 1 .

${ }^{* * *}$ Er. chrysogaster $92 \%$ : intermedius $8 \%$ based on a limited sample of males.

${ }^{* * * * *}$ Most likely Oc. juppi as Oc. caballus is rare in the subregion.

field collections $[51,55,63,113,156,172,176$, 243, 286]. However, supporting evidence for a significant epidemiological role for these species has not emerged; vector competence experiments have shown these mosquitoes to be susceptible to RVFV but incapable of transmis- sion or nearly so $[53,91,174,175,177,178$, 245, 264]. Instead, vectors in the subgenus Aedimorphus of Aedes were found to be responsible for a large outbreak in West Africa [87, 293], in particular Ae. vexans ssp. arabiensis. This mosquito was also shown to be the 
Table V. Properties of the two existing animal vaccines against Rift Valley fever virus.

\begin{tabular}{|c|c|c|}
\hline & Live-attenuated vaccine & Inactivated vaccine \\
\hline Origin/Production & $\begin{array}{l}\text { - Derived from the Smithburn vaccine } \\
\text { strain (origin = Uganda) } \\
\text { - } \text { Attenuated by successive IC }{ }^{\mathrm{a}} \text { passage in } \\
\text { newborn mice and in embryonated eggs } \\
\text { (resulting in a neurotropic strain); produced } \\
\text { in cell culture since } 1971\end{array}$ & $\begin{array}{l}\text { - Derived from South African field strain } \\
\text { - Inactivation with formaldehyde } \\
\text { - Contains adjuvant }\end{array}$ \\
\hline Advantages & $\begin{aligned}- & \text { Needs only one injection } \\
- & \text { Long duration of protective immunity } \\
& \text { (entire economic life of animals) } \\
- & \text { Inexpensive production costs }\end{aligned}$ & $\begin{array}{l}\text { - No adverse effects } \\
\text { - No contraindications }\end{array}$ \\
\hline Limitations & $\begin{aligned}- & \text { May induce abortions and fotal } \\
& \text { malformations } \rightarrow \text { major contraindications } \\
& \text { for use in pregnant animals } \\
- & \text { Transient viraemia } \\
- & \text { Possible residual human pathogenicity } \\
- & \text { Possible reassortment with } \\
& \text { field wild-type virus strains }\end{aligned}$ & $\begin{array}{l}\text { - Need two injections during the } \\
\text { first year and booster doses annually } \\
\text { - Short duration of protective immunity } \\
\text { (necessitating annual booster doses) } \\
\text { - Expensive production costs }\end{array}$ \\
\hline $\begin{array}{l}\text { Recommendations } \\
\text { for vaccine use }\end{array}$ & $\begin{array}{l}\text { - Prefer live vaccine in countries/ } \\
\text { regions where the RVF is enzootic } \\
\text { - Vaccinate before the reproductive season }\end{array}$ & $\begin{array}{l}\text { - Prefer inactivated vaccine in countries/ } \\
\text { regions newly infected or free but with a } \\
\text { high risk of RVFV introduction }\end{array}$ \\
\hline Common properties & $\begin{array}{l}\text { - Do not allow the differentiation of } \\
\text { vaccinated and naturally-infected } \\
\text { animals (i.e., no « DIVA }{ }^{\text {b }} \text { test } » \text { available) } \\
\text { - Age of vaccination: }>6 \text { month of age }\end{array}$ & \\
\hline
\end{tabular}

${ }^{\mathrm{a}} \mathrm{IC}=$ Intracranial.

${ }^{\mathrm{b}}$ DIVA test $=$ "Differentiation of infected and vaccinated animals".

likely maintenance vector in Saudi Arabia during the emergence of RVFV in 2000 [138, 185]. The epidemic/amplifying vectors in these new foci were once again members of the Culex (Culex) subgenus, namely $C x$. poicilipes [61, 62] and Culex (Culex) tritaeniorhynchus (Giles, 1901) [138].

The accepted transmission paradigm involves survival of RVFV in mosquito eggs through transovarial transmission from parous Ae. mcintoshi and Aedes (Neomelaniconion) circumluteolus (Theobald, 1908) females to their progeny during periods of drought, when the temporary water bodies dry up completely. These "floodwater" aedines oviposit on the soils surrounding the standing water and the eggs require a period of dehydration before they will hatch, potentially making them the ideal vehicle for survival of RVFV over long periods of time $[16,96,155$,
160]. When such habitats flood after rainfall, biological transmission occurs via infected mosquito saliva to domestic and wild herbivores of the family Bovidae (including cattle, buffaloes, sheep and goats) that may be attracted to the water supply. The vertebrate hosts are typically only viraemic for $2-7$ days $[56,71,173,211]$, implying that the chronic infection of the invertebrate vector is more important for survival of RVFV from season to season; the vector apparently serves as the reservoir host. Provided the larval habitats remain flooded for more than 2 or 3 weeks, the floodwater Aedes are succeeded by Culex spp., which oviposit in small egg-rafts on the surface of the water. These eggs are unable to withstand desiccation. However, the egg rafts lead to a population explosion of Culex spp. mosquitoes, which become infected upon feeding on viraemic vertebrate hosts. Whereas the 
floodwater Aedes spp. tend to remain in the immediate vicinity of the larval habitats and only feed at dusk and dawn, the more nocturnal Culex spp., e.g., Culex (Culex) theileri (Theobald, 1903), are more likely to disperse to find vertebrate hosts to feed on, leading to extensive dissemination of virus and the appearance of epidemics.

Perhaps the single most important habitat requirement in the ecology of RVFV is a shallow depression in the general topography, with water-saturated soil overlaying a poorly porous stratum (e.g., leached sands over granitic bedrock and calcic soils over clay-beds that produces standing water after heavy rainfall) [284]. Such habitats are distributed throughout the bushveld-savanna mosaic and higheraltitude grasslands of sub-Saharan Africa, where they are known colloquially as "dambos" or "pans" [2, 290] and are typically associated with sedges and grasses. However, suitable habitats are also to be found in shallow depressions in the flood-plains of rivers when floodwaters overflow the river-banks, especially in the coastal plains of eastern and southern Africa, as well as in the head-waters to rivers [155].

The West African experience differed from that seen in Kenya, Zambia, Zimbabwe and South Africa. The Aedes (Aedimorphus) spp. typically oviposit in the small, temporary ground pools that occur after localized rains. The region on either side of the Mauritanian/Senegalese border had not experienced good rainfall or floods prior to the 1987 outbreak and the typical vectors, Ae. (Neo.) mcintoshi, Ae. (Neo.) circumluteolus and $C x$. (Cux.) spp. were not present in high numbers during the entomological investigations [88]. Conditions were more ideally suited to $A e$. (Aedimorphus) spp., exemplified by Ae. vexans, Ae. ochraceus (Theobald, 1901), Ae. dalzieli (Theobald, 1910) and Ae. cumminsii (Theobald, 1903) [36]. At the time, a new dam wall had been constructed on the Senegal River; the subsequent flooding of the river banks was thought to have effected an increase in the vector and livestock population densities in the immediate vicinity of the dam [88]. With the advent of a second outbreak of RVFV in the region, investigators discovered a shift in the dominant mosquito species, namely towards Mansonia uniformis
(Theobald, 1901) and Cx. poicilipes [62]. Mansonia spp. are associated with gently flowing water and oviposit on the underside of the leaves and on the submerged roots and stems of African water lilies and water hyacinth (i.e., floating vegetation), while $C x$. poicilipes breeds in reed beds in permanent water bodies [116]. It appears that the establishment of the dam on the perennial Senegal River was responsible for the production of $C x$. poicilipes in sufficient numbers to trigger the second, larger outbreak.

The virus responsible for the 2002 RVF outbreak in the Arabian Peninsula [10, 203] appears to have been caused by introduction of the virus via imported livestock from East Africa [239]. Irrigation for agriculture in the Tihama regions of Yemen and Saudi Arabia and the proximity of the Jizan Dam provided ideal breeding grounds for both Ae. vexans and $C x$. tritaeniorhynchus and grazing of sheep and goats along the wadis and irrigation systems in the foothills of the Sarawat Mountains provided amplifying hosts [138]. The danger of RVFV spreading into the Near and Middle East and, eventually, the European Union has been touted since the 1977 Egyptian outbreak [115] and its emergence in the Red Sea coastal plain of Yemen and Saudi Arabia was seen as a significant step in the northward migration of the virus. However, RVFV has yet to escape the Afrotropical Region, bounded as it is by the Sarawat escarpment and the arid inland plateau of Saudi Arabia. Nevertheless, it is essential that potential vectors are identified in the boundary region of the Mediterranean and Middle Eastern countries, requiring surveillance to monitor species composition, species abundance and vector competence to determine vector candidates. Much still needs to be discovered about the biology of the known as well as the potential vectors, including the hypothesis of transovarial transmission. Laboratory demonstration of transovarial transmission has been hampered by the difficulty of colonizing floodwater Aedes mosquitoes. However, field studies have shown infection of both male and female mosquitoes reared from fieldcollected larvae [157] and this needs to be confirmed and investigated under controlled conditions, especially considering the report [262] of Cx. pipiens, Ae. mcintoshi and Ae. 
circumluteolus larvae becoming infected after feeding on RVFV-positive liver from an experimentally inoculated hamster.

\section{OLD AND NEW DIAGNOSTIC TOOLS FOR RVF}

There are increasing demands for highquality and procedurally safe diagnostic tests for zoonotic pathogens to ensure the best protection of human and animal populations and to facilitate the free international trade of animals and animal products. The recently documented spread of RVFV and other vector-borne zoonotic pathogens beyond their traditional endemic boundaries has resulted in increased international demand for validated diagnostic tools and specific immunoreagents for the rapid diagnosis of RVF. This demand is greatly challenged by the fact that work with RVFV requires high biocontainment facilities and, preferably, needs to be carried out by vaccinated laboratory staff, but also because the virus is regarded as a potential bioweapon agent. For these reasons, the current capacity for laboratory diagnosis of RVF is restricted to a limited number of reference laboratories worldwide. RVFV belongs to the group of RNA viral haemorrhagic fever (VHF) agents that includes Ebola, Marburg, Lassa (and other arena-), Crimean-Congo haemorrhagic fever, yellow fever, dengue and hanta-viruses. In the absence of haemorrhagic or specific organ manifestations, infections by VHF viruses are clinically difficult to recognise, with the implication that definitive diagnosis depends mainly on reliable laboratory tests. RVF may be suspected when there is a sudden outbreak of febrile illness with headache and myalgia in humans, in association with the occurrence of abortions in domestic ruminants and deaths of young animals. However, cases of RVF in humans are sometimes only recognized late after infection from the occurrence of ocular complications. Late recognition of RVFV infections typically occurs when only sporadic cases are diagnosed during inter-epizootic periods. Haemorrhagic or encephalitic manifestations might be indicative of RVFV infection, especially in the rare instances where residents of other continents develop the illness following a visit to endemic areas in Africa. Experiences from the more recent outbreaks in Africa and the Arabian Peninsula appear to indicate that outbreaks of RVF in livestock are only recognized after diagnosis of the disease in humans.

Diagnosis of RVF is achieved using various techniques, including virus isolation [7, 240], antigen detection [181, 208] and nucleic acid amplification techniques [66, 93, 121] and by detection of specific antibodies [251]. RVFV is readily isolated from serum or whole blood during the febrile stage of the disease as well as from the liver, spleen and brain of fresh carcasses/cadavers or aborted foetuses. Isolation of the virus is achieved in hamsters, infant or adult mice and in various cell cultures [99, 253]. However, virus isolation procedures are lengthy and expensive. Delays in diagnosis based on traditional virus isolation and identification techniques may represent a significant problem for regulatory healthcare authorities faced with a RVF epidemic, especially in countries outside its traditional geographical confines. Hence, considerable efforts have recently been made to develop nucleic acid techniques for the rapid detection and identification of RVFV.

Highly sensitive PCR assays for the detection and quantification of RVFV have been reported, including RT-PCR [93, 121, 235] and real-time detection PCR (RTD-PCR) based on TaqMan probe technology $[18,66]$. More recently, real-time reverse-transcription loopmediated isothermal amplification assays (RTLAMP) targeting the large RNA segment were developed and evaluated for the detection of a wide spectrum of RVFV isolates and clinical specimens [152, 223]. The RT-LAMP detection limit was reported to be $0.065 \mathrm{TCID}_{50}$ per reaction volume [152] and $\sim 10$ RNA copies per assay [223], and there was $100 \%$ agreement between the RT-LAMP, TaqMan-based RTDPCR and virus isolation results [152]. Similarly, the assay had a very high diagnostic sensitivity and specificity when testing various clinical specimens from humans and animals that were naturally infected with the virus during recent outbreaks of RVF in Africa. The detection of specific viral genome targets in positive clinical 
specimens using the RT-LAMP is achieved in less than $30 \mathrm{~min}$. Apart from high analytical and diagnostic accuracy and speed of detection, another important practical advantage of the LAMP assay is that it utilizes simple and relatively inexpensive equipment which renders it promising for use in resource-poor settings and as a portable device during RVF outbreaks in remote areas [152, 223]. During the 2006 RVF outbreak in Kenya, quantitative real-time RT-PCR (qRT-PCR) was evaluated to identify patients with high viraemia, which is associated with poor prognosis [210]. This was the first report of qRT-PCR being used for case-confirmation and for correlation of RVFV-RNA levels, measured by qRT-PCR, with infectious virus titres. Fatal RVF cases had over 3-fold higher levels of viral RNA (mean $=8.6 \times 10^{6}$ viral RNA copies/mL of serum) and 3-logs higher infectious virus concentrations ( $10^{5.2}$ infectious virus particles $/ \mathrm{mL}$ of serum) when compared to non-fatal cases (means of $2.4 \times 10^{6}$ viral RNA copies $/ \mathrm{mL}$ and $10^{2.3}$ infectious virus particles $/ \mathrm{mL}$ of serum). The findings in Kenyan [210] and Saudi Arabian [18] patients sampled during the 2000 outbreak of RVF, indicate that qRT-PCR can be used for the rapid identification of patients with high viraemia and poor prognosis, thereby enabling them to be targeted for special or intensive clinical management.

One has to emphasize, however, that definitive diagnosis or exclusion of RVF, as of any other suspected VHF case, should not rely on a single PCR result. The nucleic acid detection assays should be run in parallel with additional tests, including detection of type-specific antibodies to RVFV. In this context it is important to note that viraemia in RVFV-infected individuals is of very short duration and most infected patients and adult ruminants undergo subclinical or mild infections; however, IgM and IgG antibodies are easily demonstrable shortly after exposure to the virus [213-215]. Furthermore, most nucleic acid techniques require highly specialized laboratory equipment, sophisticated reagents and well trained laboratory personnel, which conditions may not be available when outbreaks occur in remote regions and when rapid diagnosis is necessary.
Viral antigen can be detected rapidly in blood and other tissues by a variety of immunological methods, including agar gel immunodiffusion using homogenised tissues and immunostaining on impression smears or on cryostat sections of liver, spleen and brain; these assays allow the specific identification of the RVFV antigen in infected cells. Histopathological examination of the liver of affected animals reveals a characteristic cytopathology $[99,253]$. Enzyme-linked immunosorbent assays (ELISA) for the detection of RVFV antigen have also been reported, but most of these assays were based on reagents that are cumbersome and expensive to produce and pose a biohazard risk to laboratory personnel [181, 208, 292]. Recently, Zaki et al. [292] reported on immunofluorescence assays which utilize a pool of mouse IgG monoclonal conjugates reacting with a combination of virus specific antigens (Gs, $G_{n}, N$, NSs). Although it was demonstrated to be highly reliable in detecting RVFV in patient sera, its use requires tissue culture amplification and handling of live virus. A number of laboratory infections with RVFV were recorded under circumstances which indicate the virus to be highly infectious for man $[83,142,246]$. To address this problem, a sandwich ELISA for antigen detection (sAg-ELISA) based on an entirely safe procedure, including a set of internal controls based on a recombinant nucleocapsid protein (recNP) for monitoring of routine assay performance, which increases its utility in surveillance and diagnosis in nonendemic areas, was recently reported [131]. The assay was developed for the detection of the nucleocapsid protein (NP) of RVFV in specimens that had been inactivated at $56{ }^{\circ} \mathrm{C}$ for $1 \mathrm{~h}$ in the presence of $0.5 \%$ Tween-20 $(\mathrm{v} / \mathrm{v})$ before testing. The sAg-ELISA has been used to detect strains of RVFV, that were isolated in geographically distinct areas of the world over a period of 53 years, with no cross-reactivity with the related African phleboviruses or other members of the family Bunyaviridae. The detection limits ranged from $\log _{10} 10^{2.2}$ to $10^{3.2} \mathrm{TCID}_{50} /$ reaction volume. Compared to virus isolation results in sera from RVF patients and experimentally infected sheep, the sAg-ELISA had $67.7 \%$ and $70 \%$ sensitivity, and $97.97 \%$ and $100 \%$ 
specificity, respectively. The assay was $100 \%$ accurate when testing tissues of various organs from experimentally infected mice and naturally infected buffalo foetuses. The assay was able to detect NP antigen in infected culture supernatants 12 to $30 \mathrm{~h}$ before cytopathic effects were observed and as early as $8 \mathrm{~h}$ after inoculation with $10^{5.8} \mathrm{TCID}_{50} / \mathrm{mL}$ of RVFV. This ability renders the assay suitable for rapid identification of the virus when its primary isolation is attempted in vitro. As a highly specific, safe and simple assay, the sAg-ELISA represents a valuable diagnostic tool for use in less wellequipped laboratories in Africa and for routine differential diagnosis of VHF [131].

Serum specimens are commonly used for RVF diagnosis. Viraemia titers ranging from $10^{5.6}$ to $10^{9.0}$ mouse $\mathrm{LD}_{50} / \mathrm{mL}$ have been recorded in domestic ruminants $[12,51,111$, $188,252], 10^{8.6}$ mouse $\mathrm{LD}_{50} / \mathrm{mL}$ in humans [220] and $10^{5.4} \mathrm{TCID}_{50} / \mathrm{mL}$ in adult African buffalo [56]. Although viraemia in RVFVinfected individuals reaches high titres, it is of short duration, limiting its use for viral detection systems for RVF outbreak diagnosis. Therefore, attempts to detect recent RVFV infection by ELISA should include a combination of assays which target both viral antigens and IgM antibody. In contrast, RVFV can persist at high titers for 21 days in ovine brain and liver and up to 30 days in spleen [289]. The high diagnostic accuracy of the sAgELISA for detecting RVFV in infected tissues, which usually contain virus concentrations at least 10- to 100-fold times above the detection limits determined for the assay [70, 111, 188], thus renders it ideal for testing specimens from aborted foetuses and carcasses/cadavers. Sudden, high abortion and fatality rates in young animals are characteristic features of RVF outbreaks.

Diagnosis of infectious diseases can be made when serological tests are used in combination with clinical observations and, epidemiological history or when seroconversion is demonstrated. Serodiagnostic techniques are also widely used to demonstrate freedom from a disease and in epidemiological investigations. The classical methods for the detection of antibodies to RVFV include haemagglutination-inhibition, complement fixation, indirect immunofluorescence and virus neutralization tests (VNT) $[99,251]$. The disadvantages of these techniques include health risks to laboratory personnel $[142,177,246,268]$ and restrictions for their use outside RVF endemic areas. Diagnosis of recent infection is confirmed by demonstrating seroconversion or a 4-fold or greater rise in titre of antibody in paired serum samples, or by demonstrating $\operatorname{IgM}$ antibody activity in an ELISA [215, 217].

Although regarded as the gold standard, the VNT is laborious, expensive and requires 5-7 days for completion. It can be performed only when standardized stocks of live virus and tissue cultures are available. Consequently, it is rarely used and then only in highly specialized reference laboratories. However, from the point of view of using the VNT as a diagnostic discriminator in validation studies, it is important to note that infection with RVFV induces lifelong neutralizing immunity and that there is no evidence for the existence of serological subgroups or major antigenic variation between virus isolates of disparate chronologic or geographic origins [253]. The VNT is highly accurate with little or no cross-neutralization with other phleboviruses [54, 249, 251, 255] but since it requires live virus, it can only be done in suitable biocontainment facilities.

Various ELISA formats developed in recent years for the specific detection of $\operatorname{IgG}, \operatorname{IgM}$ or total antibodies, based on inactivated sucroseacetone-extracted antigens derived from tissue culture or mouse brain were shown to be highly accurate diagnostic tools in disease surveillance and control programs, import/export veterinary certification and for monitoring of immune response in vaccines [32, 213-216, 219]. As highly accurate, robust and safe tests, they have the potential to replace traditional diagnostic methods which pose health risks and necessitate their use being restricted to high containment facilities outside RVF-endemic areas. However, the production of antigen for these assays also requires bio-containment facilities to limit the risk of exposure of laboratory personnel to infection. To address these problems, an indirect ELISA based on the recNP of RVFV has recently been developed for the detection of 
specific antibodies in human and animal sera $[79,130,217,218]$. The nucleocapsid protein appears to be highly conserved among members of the Bunyaviridae family [97, 165, 237, 269] and antigenic cross-reactivity studies in animals [54, 249, 252] and the indirect ELISA based on recNP [217] failed to provide any evidence that other African phleboviruses could obscure the reliable serodiagnosis of RVF. As the most abundant and highly immunogenic viral component in the RVFV virion, NP seems to be the best choice for the development of immunoreagents for antigen detection assays. The fact that a soluble, highly purified recombinant RVF NP can be produced easily in large quantities [130], will allow for less expensive, fully automated mass-screening of sera. Research efforts aimed at the development and validation of a new generation of safe diagnostic immunoreagents and assays, for example ELISA formats based on RVFV recombinant antigens, are strongly recommended since cloning and expression of RVFV antigens would avoid the risk of laboratory infections and of residual virus in the test reagents, making them safe for routine use in RVF-free areas. However, it still remains to be proven through extensive validation studies that recombinant antigen-based ELISA would have at least the same diagnostic accuracy in livestock populations from various geographic regions as ELISA based on the whole inactivated antigen of the virus.

\section{PREVENTION AND VACCINES}

\subsection{Existing vaccines}

Because of the socio-economical impact of RVF in Africa, it appeared that vaccines, at least for veterinary use, were urgently needed. The first vaccine, still in use, was developed by Smithburn [244] who adapted the Entebbe isolate by serial intracerebral inoculation of mice to attenuate the virulence, a procedure first used by Theiler to produce the yellow fever 17D vaccine [256]. However, the passaged virus, called the Smithburn strain, had only partially lost its virulence: it induced abortions and tera- togenesis in ewes, cows and goats [24, 139, $154,253]$, so that its use is mainly restricted for use during devastating outbreaks and only in non-pregnant female animals $[13,253]$. To circumvent these difficulties, an inactivated vaccine has been produced, allowing the safe vaccination of animals, but this vaccine is not as efficacious as the attenuated vaccines and needs booster inoculations [12] (Tab. V). After the Egyptian outbreak in 1977, USAMRIID initiated research to produce a new RVFV vaccine. The attenuated MP12 was obtained from the virulent Egyptian strain (ZH548) after random mutagenesis with 5-fluorouracil during 12 successive passages [30]. This virus acquired mutations in all three segments and had lost its virulence when tested in mice [236, 270]. Moreover, it was shown to induce a good immunity in ruminants after experimental inoculation [190, 192, 193]. However, trials carried out in South Africa using pregnant ewes revealed some abortions and teratogenesis during the early stages of pregnancy [119]. This might corroborate data reporting that MP12 still had some neurovirulence when inoculated into hamsters, which constitute a very sensitive animal model [230]. At the present time and in spite of these data, MP12 is still being developed as a veterinary and human vaccine. An alternative candidate based on another RVFV isolate, Clone 13, was found to be avirulent due to a large deletion in the NSs protein [201]. This virus grows to high titers in cell cultures and the deletion in the sequence coding for the virulence factor made it attractive due to its inability to revert. Vaccination trials in sheep, including ewes, and in bovines were carried out. Not only did the virus not provoke any deleterious effects but the animals elicited a high antibody response and were protected against a virulent challenge. Pregnant ewes were also protected from abortions, which were observed in the unvaccinated control animals ${ }^{3}$.

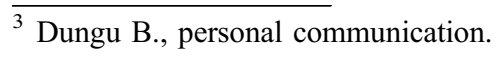




\subsection{Designing new vaccines}

While Clone 13 is a natural virus originating from a mild RVF case, it is now possible to manipulate the viral genome via reverse genetics to produce similar or different viruses, opening new ways to abrogate its pathogenicity [26]. This has been demonstrated by producing a rMP12 in which the S segment carries a mutation identical to the one in Clone 13 [124] or by removing the complete NSs sequence from MP12 or from the otherwise virulent backbone of the strain ZH501 [20]. In addition, because NSm plays a role as an anti-apoptotic factor, a double mutant $\Delta \mathrm{NSs} / \mathrm{NSm}$ abrogating expression of both NSs and NSm proteins was created and shown to be avirulent and to confer complete protection against virulent virus challenge at dosages up to $1.0 \times 10^{4} \mathrm{LD}_{50}$ in the rat model [20] and in mice ${ }^{4}$.

Sub-unit recombinant vaccine candidates expressing the RVFV glycoproteins have been described: different vectors such as the lumpy skin disease virus [276, 277], an alphavirus [105, 112], a non-replicating adenovirus [114], or the Newcastle disease virus [145] were used. Other groups have developed sub-unit vaccines by expressing the RVFV glycoproteins which can assemble into "empty" virus-like particles or VLP [58, 108, 159, 204]. For efficient production, recombinant baculoviruses were constructed expressing the glycoproteins alone or in association with $\mathrm{N}$ [159]. DNA-based vaccine administrated by gene gun has also been described but required several reimmunizations [147, 247, 277].

Interestingly, most of the vaccine candidates, whether live-attenuated virus or sub-unit vaccine, have some genes missing when compared to natural strains circulating in the wild. This was also the case with Clone 13, its truncated NSs being degraded rapidly by the proteasome [271]. This raised the question of vaccine being able to distinguish infected from vaccinated animals (DIVA) [20]. An ELISA based on the detection or non-detection of antibodies against the NSs protein was developed recently [171]. The test was evaluated using sera from experi-

\footnotetext{
$\overline{{ }^{4} \text { Bird B., unpublished results. }}$
}

mentally infected rats and from a small number of ruminants which had antibody against the NSs protein, although of low titer. Considering that NSs is poorly immunogenic, a survey of a large number of animals should be done to determine if a high proportion of naturally infected livestock elicits a detectable and long-lasting immune response against this protein.

\section{CONCLUSION}

This review demonstrates that RVFV has become an important subject of interest over the past three decades and particularly in recent years, as public health agencies have become alerted to the possible emergence of this arbovirus in temperate countries. Climate change [170] and the presence of competent vectors in currently RVF-free temperate countries [199, 266, 280] suggests strongly that RVFV should be included among the most significant emerging viral threats to public and veterinary health. Recent insights into the virus' pathogenesis, molecular epidemiology, diagnostics and the increasing number of vaccine trials using various modern approaches, including reverse genetics, recombinant vectors, VLP, subunit vaccines and DNA vaccines [26, 126], have contributed greatly to our understanding of this significant viral pathogen. Despite these efforts, safe and efficient vaccines, both for medical and veterinary use, are still lacking, even though they are essential for the protection of animal and human populations and reduction of the dramatic health impacts of outbreaks, wherever they may occur. The recent outbreaks in Egypt and in the Arabian Peninsula have illustrated the potential of RVFV to spread to previously unaffected areas, leading to the following warning, cited by Zabransky (2005) [291] by Dr Corrie Brown (University of Georgia, USA): "If we get Rift Valley fever [in the USA], it would make West Nile look like a hiccup."

\section{REFERENCES}

[1] Abu-Elyazeed R., El-Sharkawy S., Olson J., Botros B., Soliman A., Salib A., et al., Prevalence of anti-Rift-Valley-fever IgM antibody in abattoir 
workers in the Nile delta during the 1993 outbreak in Egypt, Bull. World Health Organ. (1996) 74:155-158.

[2] Ackermann E., Dambos in Nordrhodesien, Wissenschaftliche Veröffenlichungen, Museum fur Landerkunde der Leipzig (1936) 4:147-157.

[3] Albarino C.G., Bird B.H., Nichol S.T., A shared transcription termination signal on negative and ambisense RNA genome segments of Rift Valley fever, sandfly fever Sicilian, and Toscana viruses, J. Virol. (2007) 81:5246-5256.

[4] Anderson G.W. Jr, Slone T.W. Jr, Peters C.J., Pathogenesis of Rift Valley fever virus (RVFV) in inbred rats, Microb. Pathog. (1987) 2:283-293.

[5] Anderson G.W. Jr, Smith J.F., Immunoelectron microscopy of Rift Valley fever viral morphogenesis in primary rat hepatocytes, Virology (1987) 161:91-100.

[6] Anderson G.W. Jr, Peters C.J., Viral determinants of virulence for Rift Valley fever (RVF) in rats, Microb. Pathog. (1988) 5:241-250.

[7] Anderson G.W. Jr, Saluzzo J.F., Ksiazek T.G., Smith J.F., Ennis W., Thureen D., et al., Comparison of in vitro and in vivo systems for propagation of Rift Valley fever virus from clinical specimens, Res. Virol. (1989) 140:129-138.

[8] Anderson G.W. Jr, Lee J.O., Anderson A.O., Powell N., Mangiafico J.A., Meadors G., Efficacy of a Rift Valley fever virus Vaccine against an aerosol infection in rats, Vaccine (1991) 9:710-714.

[9] Andrewes C.H., Horstmann D.M., The susceptibility of viruses to ethyl ether, J. Gen. Virol. (1949) 3:290-297.

[10] Arishi H., Ageel A., Rahman M.A., Hazmi A.A., Arishi A.R., Ayoud Menon B., et al., Outbreak of Rift Valley fever-Saudi Arabia, August-October, 2000, MMWR Morb. Mortal. Wkly Rep. (2000) 49:905908.

[11] Balkhy H.H., Memish Z.A., Rift Valley fever: An uninvited zoonosis in the Arabian peninsula, Int. J. Antimicrob. Agents (2003) 21:153-157.

[12] Barnard B.J., Botha M.J., An inactivated Rift Valley fever vaccine, J. S. Afr. Vet. Assoc. (1977) 48:45-48.

[13] Barnard B.J.H., Rift Valley fever vaccine-antibody and immune response in cattle to a live and an inactivated vaccine, J. S. Afr. Vet. Assoc. (1979) $50: 155-157$.

[14] Battles J.K., Dalrymple J.M., Genetic variation among geographic isolates of Rift Valley fever virus, Am. J. Trop. Med. Hyg. (1988) 39:617-631.
[15] Beaty B.J., Rozhon E.J., Gensemer P., Bishop D.H., Formation of reassortant bunyaviruses in dually infected mosquitoes, Virology (1981) 111:662-665.

[16] Becker N., Life strategies of mosquitoes as an adaptation to their habitats, Bull. Soc. Vector Ecol. (1989) 14:6-25.

[17] Billecocq A., Gauliard N., Le May N., Elliott R.M., Flick R., Bouloy M., RNA polymerase I-mediated expression of viral RNA for the rescue of infectious virulent and avirulent Rift Valley fever viruses, Virology (2008) 378:377-384.

[18] Bird B.H., Baweic D.A., Ksiazek T.G., Shoemaker T.R., Nichol S.T., Highly sensitive and broadly reactive quantitative RT-PCR assay for high throughput detection of Rift Valley fever virus, J. Clin. Microbiol. (2007) 45:3506-3513.

[19] Bird B.H., Khristova M.L., Rollin P.E., Ksiazek T.G., Nichol S.T., Complete genome analysis of 33 ecologically and biologically diverse Rift Valley Fever virus strains reveals widespread virus movement and low genetic diversity due to recent common ancestry, J. Virol. (2007) 81:2805-2816.

[20] Bird B.H., Albarino C.G., Hartman A.L., Erickson B.R., Ksiazek T.G., Nichol S.T., Rift Valley fever virus lacking the NSs and NSm genes is highly attenuated, confers protective immunity from virulent virus challenge, and allows for differential identification of infected and vaccinated animals, J. Virol. (2008) 82:2681-2691.

[21] Bird B.H., Githinji J.W.K., Macharia J.M., Kasiiti J.L., Muriithi R.M., Gacheru S.G., et al., Multiple virus lineages sharing recent common ancestry were associated with a large Rift Valley fever outbreak among livestock in Kenya during 20062007, J. Virol. (2008) 82:11152-11166.

[22] Bird B.H., Ksiazek T.G., Nichol S.T., Maclachlan N.J., Rift Valley fever virus, J. Am. Vet. Med. Assoc. (2009) 234:883-893.

[23] Borucki M.K., Chandler L.J., Parker B.M., Blair C.D., Beaty B.J., Bunyavirus superinfection and segment reassortment in transovarially infected mosquitoes, J. Gen. Virol. (1999) 80:3173-3179.

[24] Botros B., Omar A., Elian K., Mohamed G., Soliman A., Salib A., et al., Adverse response of nonindigenous cattle of European breeds to live attenuated Smithburn Rift Valley fever vaccine, J. Med. Virol. (2006) 78:787-791.

[25] Bouloy M., Dufour B., André-Fontaine G., Albina E., Chevalier V., Dorchies P., et al., REPORT: Risque de propagation de la fièvre de la vallée du Rift (FVR) dans l'Océan Indien (La Réunion et Mayotte), AFSSA, Maisons-Alfort, France, www.afssa.fr, 2008, pp. $1-124$. 
[26] Bouloy M., Flick R., Reverse genetics technology for Rift Valley fever virus: Current and future applications for the development of therapeutics and vaccines, Antiviral Res. (2009) 84:101-118.

[27] Breiman R.F., Njenga M.K., Cleaveland S., Sharif S.K., Mbabu M., King L., Lessons from the 2006-2007 Rift Valley fever outbreak in East Africa: Implications for prevention of emerging infectious diseases, Future Virol. (2008) 3:411-417.

[28] Briese T., Bird B., Kapoor V., Nichol S.T., Lipkin W.I., Batai and Ngari viruses: $M$ segment reassortment and association with severe febrile disease outbreaks in East Africa, J. Virol. (2006) 80:5627-5630.

[29] Brown J.L., Dominik J.W., Morrissey R.L., Respiratory infectivity of a recently isolated Egyptian strain of Rift Valley fever virus, Infect. Immun. (1981) 33:848-853.

[30] Caplen H., Peters C.J., Bishop D.H.L., Mutagendirected attenuation of Rift Valley fever virus as a method for vaccine development, J. Gen. Virol. (1985) 66:2271-2277.

[31] Carroll S.A., Bird B.H., Rollin P.E., Nichol S.T., Ancient common ancestry of Crimean-Congo hemorrhagic fever virus, Mol. Phylogenet. Evol. (2010) 55:1103-1110.

[32] Cetre-Sossah C., Billecocq A., Lancelot R., Defernez C., Favre J., Bouloy M., et al., Evaluation of a commercial competitive ELISA for the detection of antibodies to Rift Valley fever virus in sera of domestic ruminants in France, Prev. Vet. Med. (2009) 90:146149 .

[33] Chambers P.G., Swanepoel R., Rift Valley Fever in abattoir workers, Cent. Afr. J. Med. (1980) 26:122126.

[34] Chandler L.J., Hogge G., Endres M., Jacoby D.R., Nathanson N., Beaty B.J., Reassortment of La Crosse and Tahyna bunyaviruses in Aedes triseriatus mosquitoes, Virus Res. (1991) 20:181-191.

[35] Chevalier V., De La Rocque S., Baldet T., Vial L., Roger F., Epidemiological processes involved in the emergence of vector-borne diseases: West Nile fever, Rift Valley fever, Japanese encephalitis and Crimean-Congo haemorrhagic fever, OIE Rev. Sci. Tech. (2004) 23:535-555.

[36] Chevalier V., Mondet B., Diaite A., Lancelot R., Fall A.G., Ponçon N., Exposure of sheep to mosquito bites: Possible consequences for the transmission risk of Rift Valley Fever in Senegal, Med. Vet. Entomol. (2004) 18:247-255.

[37] Chevalier V., Pépin M., Plée L., Lancelot R., Rift Valley fever - A threat for Europe?, Eurosurveillance
(2010) 15:pii-19506 (Available online: http://www. eurosurveillance.org/ViewArticle.aspx?Articled=19506).

[38] Clements A.C., Pfeiffer D.U., Emerging viral zoonoses: frameworks for spatial and spatiotemporal risk assessment and resource planning, Vet. J. (2009) 182:21-30.

[39] Clements A.C.A., Pfeiffer D.U., Martin V., Otte M.J., A Rift Valley fever atlas for Africa, Prev. Vet. Med. (2007) 82:72-82.

[40] Clements A.C.A., Pfeiffer D.U., Martin V., Pittliglio C., Best N., Thiongane Y., Spatial risk assessment of Rift Valley fever in Senegal, Vector Borne Zoonotic Dis. (2007) 7:203-216.

[41] Coackley W., Pini A., Gosden D., Experimental infection of cattle with pantropic Rift Valley fever virus, Res. Vet. Sci. (1967) 8:399-405.

[42] Coetzer J.A., The pathology of Rift Valley fever. I. Lesions occurring in natural cases in new-born lambs, Onderstepoort J. Vet. Res. (1977) 44:205-211.

[43] Coetzer J.A., The pathology of Rift Valley fever. II. Lesions occurring in field cases in adult cattle, calves and aborted foetuses, Onderstepoort J. Vet. Res. (1982) 49:11-17.

[44] Coetzer J.A., Ishak K.G., Sequential development of the liver lesions in new-born lambs infected with Rift Valley fever virus. I. Macroscopic and microscopic pathology, Onderstepoort J. Vet. Res. (1982) 49:103-108.

[45] Coetzer J.A., Ishak K.G., Calvert R.C., Sequential development of the liver lesions in new-born lambs infected with Rift Valley fever virus. II. Ultrastructural findings, Onderstepoort J. Vet. Res. (1982) 49:109-122.

[46] Collett M.S., Purchio A.F., Keegan K., Frazier S., Hays W., Anderson D.K., et al., Complete nucleotide sequence of the M RNA segment of Rift Valley fever virus, Virology (1985) 144:228-245.

[47] Collett M.S., Messenger RNA of the M segment RNA of Rift Valley fever virus, Virology (1986) 151:151-156.

[48] Conzelmann K.K., Cox J.H., Thiel H.J., An L (polymerase)-deficient rabies virus defective interfering particle RNA is replicated and transcribed by heterologous helper virus L proteins, Virology (1991) 184:655-663.

[49] Craig D.E., Thomas W.J., DeSanctis A.N., Stability of Rift Valley fever virus at 4 C, Appl. Microbiol. (1967) 15:446-447.

[50] Dasgupta A., Targeting TFIIH to inhibit host cell transcription by Rift Valley fever virus, Mol. Cell (2004) 13:456-458. 
[51] Daubney R., Hudson J.R., Garnham P.C., Enzootic hepatitis or Rift Valley fever. An undescribed virus disease of sheep, cattle and man from East Africa, J. Pathol. Bacteriol. (1931) 34:545-579.

[52] Daubney R., Hudson J.R., Rift Valley fever, Lancet (1932) 1:611-612.

[53] Daubney R., Hudson J.R., Rift Valley fever, East Afr. Med. J. (1933) 10:2-19.

[54] Davies F.G., Observations on the epidemiology of Rift Valley fever in Kenya, J. Hyg. (1975) 75:219230 .

[55] Davies F.G., Highton R.B., Possible vectors of Rift Valley fever in Kenya, Trans. R. Soc. Trop. Med. Hyg. (1980) 74:815-816.

[56] Davies F.G., Karstad L., Experimental infection of the African buffalo with the virus of Rift Valley fever, Trop. Anim. Health Prod. (1981) 13:185-188.

[57] Davoust B., Marie J.L., Boni M., Prevention of zoonoses: creation of a unit for early detection of animal infections, Bull. Acad. Natl Méd. (2008) 192:541-554 (in French).

[58] De Boer S.M., Kortekaas J., Antonis A.F., Kant J., van Oploo J.L., Rottier P.J., et al., Rift Valley fever virus subunit vaccines confer complete protection against a lethal virus challenge, Vaccine (2010) 28:2330-2339.

[59] Deyde V.M., Khristova M.L., Rollin P.E., Ksiazek T.G., Nichol S.T., Crimean-Congo hemorrhagic fever virus genomics and global diversity, J. Virol. (2006) 80:8834-8842.

[60] Diallo B., Thonnon J., Traore-Lamizana M., Fontenille D., Vectors of chikungunya virus in Senegal: current data and transmission cycles, Am. J. Trop. Med. Hyg. (1999) 60:281-286.

[61] Diallo M., Lochouarn L., Ba K., Sall A.A., Mondo M., Girault L., Mathiot C., First isolation of the Rift Valley fever virus from Culex poicilipes (Diptera: Culicidae) in nature, Am. J. Trop. Med. Hyg. (2000) 62:702-704.

[62] Diallo M., Nabeth P., Ba K., Sall A.A., Ba Y., Mondo M., et al., Mosquito vectors of the 1998-1999 outbreak of Rift Valley Fever and other arboviruses (Bagaza, Sanar, Wesselsbron and West Nile) in Mauritania and Senegal, Med. Vet. Entomol. (2005) 19:119-126.

[63] Digoutte J.P., Cordellier R., Robin Y., Pajot F.X., Geoffroy B., Le virus zinga (Ar B 1976), nouveau prototype d'arbovirus isolé en République Centrafricaine, Ann. Microbiol. (Paris) (1974) 125B:107-118.
[64] Dohm D.J., Rowton E.D., Lawyer P.G., O’Guinn M., Turell M.J., Laboratory transmission of Rift Valley fever virus by Phlebotomus duboscqi, Phlebotomus papatasi, Phlebotomus sergenti, and Sergentomyia schwetzi (Diptera: Psychodidae), J. Med. Entomol. (2000) 37:435-438.

[65] Drake J.W., Holland J.J., Mutation rates among RNA viruses, Proc. Natl. Acad. Sci. USA (1999) 96:13910-13913.

[66] Drosten C., Göttig S., Schilling S., Asper M., Panning M., Schmitz H., Günther S., Rapid detection and quantification of RNA of Ebola and Marburg viruses, Lassa virus, Crimean-Congo hemorrhagic fever virus, Rift Valley fever virus, dengue virus, and yellow fever virus by real-time reverse transcription-PCR, J. Clin. Microbiol. (2002) 40:2323-2330.

[67] Drummond A.J., Ho S.Y., Phillips M.J., Rambaut A., Relaxed phylogenetics and dating with confidence, PLoS Biol. (2006) 4:e88.

[68] Drummond A.J., Rambaut A., BEAST: Bayesian evolutionary analysis by sampling trees, BMC Evol. Biol. (2007) 7:214.

[69] Dufour B., Moutou F., Hattenberger A.M., Rodhain F., Global change: impact, management, risk approach and health measures - the case of Europe, Rev. Sci. Tech. Off. Int. Epizoot. (2008) 27:529-550.

[70] Easterday B.C., McGavran M.H., Rooney J.R., Murphy L.C., The pathogenesis of Rift Valley fever in lambs, Am. J. Vet. Res. (1962) 23:470-479.

[71] Easterday B.C., Murphy L.C., Bennett D.G., Experimental Rift Valley fever in calves, goats and pigs, Am. J. Vet. Res. (1962) 23:1224-1230.

[72] Easterday B.C., Murphy L.C., Bennett D.G., Experimental Rift Valley fever in lambs and sheep, Am. J. Vet. Res. (1962) 23:1231-1240.

[73] Eddy G.A., Peters C.J., Meadors G., Cole F.E. Jr, Rift valley fever vaccine for humans, in: Swartz T.A., Klinberg M.A., Goldblum N., Papier C.M. (Eds.), Contributions to epidemiology and biostatistics: Rift Valley fever, S. Karger AG, Basel, 1981, pp. 124-141.

[74] Elliott R.M., Molecular biology of the Bunyaviridae, J. Gen. Virol. (1990) 71:501-522.

[75] Elliott R.M., The Bunyaviridae, Plenum Press, New York \& London, 1996.

[76] Elliott R.M., Weber F., Bunyaviruses and the type I interferon system, Viruses (2009) 1:1003-1021.

[77] Ellis D.S., Simpson D.I.H., Stamford S., Wahab K.S.E.A., Rift Valley fever virus: Some ultrastructural 
observations on material from the outbreak in Egypt 1977, J. Gen. Virol. (1979) 42:329-337.

[78] Erasmus B.J., Coetzer J.A., The symptomatology and pathology of Rift Valley fever in domestic animals, in: Swartz T.A., Klinberg M.A., Goldblum N., Papier C.M. (Eds.), Contributions to epidemiology and biostatistics: Rift Valley fever, S. Karger AG, Basel, 1981, pp. 77-82.

[79] Fafetine J.M., Tijhaar E., Paweska J.T., Neves L.C.B.G., Hendriks J., Swanepoel R., et al., Cloning and expression of Rift Valley fever virus nucleocapsid (N) protein and evaluation of a $\mathrm{N}$-protein based indirect ELISA for the detection of specific $\operatorname{IgG}$ and IgM antibodies in domestic ruminants, Vet. Microbiol. (2007) 121:29-38.

[80] Fagbami A.H., Tomori O., Fabiyi A., Isoun T.T., Experimental Rift Valley fever in West African Dwarf sheep, Res. Vet. Sci. (1975) 18:334-335.

[81] Faran M.E., Romoser W.S., Routier R.G., Bailey C.L., The distribution of Rift Valley fever virus in the mosquito Culex pipiens as revealed by viral titration of dissected organs and tissues, Am. J. Trop. Med. Hyg. (1988) 39:206-213.

[82] Filone C.M., Heise M., Doms R.W., BertolottiCiarlet A., Development and characterization of a Rift Valley fever virus cell-cell fusion assay using alphavirus replicon vectors, Virology (2006) 356:155-164.

[83] Findlay G.M., Rift Valley fever or enzootic hepatitis, Trans. R. Soc. Trop. Med. Hyg. (1932) 25:229-265.

[84] Flick R., Pettersson R.F., Reverse genetics system for Uukuniemi virus (Bunyaviridae): RNA polymerase I-catalyzed expression of chimeric viral RNAs, J. Virol. (2001) 75:1643-1655.

[85] Flick R., Bouloy M., Rift Valley fever virus, Curr. Mol. Med. (2005) 5:827-834.

[86] Fontenille D., Traore-Lamizana M., Trouillet J., Leclerc A., Mondo M., Ba Y., et al., First isolations of arboviruses from phlebotomine sand flies in West Africa, Am. J. Trop. Med. Hyg. (1994) 50: $570-574$.

[87] Fontenille D., Traore-Lamizana M., Zeller H., Mondo M., Diallo M., Digoutte J.P., Short report: Rift Valley fever in Western Africa: Isolations from Aedes mosquitoes during an interepizootic period, Am. J. Trop. Med. Hyg. (1995) 52:403-404.

[88] Fontenille D., Traore-Lamizana M., Diallo M., Thonnon J., Digoutte J.P., Zeller H.G., New vectors of Rift Valley fever in West Africa, Emerg. Infect. Dis. (1998) 4:289-293.
[89] Freiberg A.N., Sherman M.B., Morais M.C., Holbrook M.R., Watowich S.J., Three-dimensional organization of Rift Valley fever virus revealed by cryoelectron tomography, J. Virol. (2008) 82:1034110348.

[91] Gad A.M., Hassan M.M., el Said S., Moussa M.I., Wood O.L., Rift Valley fever virus transmission by different Egyptian mosquito species, Trans. R. Soc. Trop. Med. Hyg. (1987) 81:694-698.

[92] Gale P., Brouwer A., Ramnial V., Kelly L., Kosmider R., Fooks A.R., Snary E.L., Assessing the impact of climate change on vector-borne viruses in the EU through the elicitation of expert opinion, Epidemiol. Infect. (2010) 138:214-225.

[93] Garcia S., Crance J.M., Billecocq A., Peinnequin A., Jouan A., Bouloy M., Garin D., Quantitative realtime PCR detection of Rift Valley fever virus and its application to evaluation of antiviral compounds, J. Clin. Microbiol. (2001) 39:4456-4461.

[94] Gargan T.P. II, Bailey C.L., Higbee G.A., The effect of laboratory colonization on the vector-pathogen interactions of Egyptian Culex pipiens and Rift Valley fever virus, Am. J. Trop. Med. Hyg. (1983) 32:1154-1163.

[95] Gargan T.P. II, Clark G.G., Dohm D.J., Turell M.J., Bailey C.L., Vector potential of selected North American mosquito species for Rift Valley fever virus, Am. J. Trop. Med. Hyg. (1988) 38:440-446.

[96] Gargan T.P. II, Jupp P.G., Novak R.J., Panveld oviposition sites of floodwater Aedes mosquitoes and attempts to detect transovarial transmission of Rift Valley fever virus in South Africa, Med. Vet. Entomol. (1988) 2:231-236.

[97] Gauliard N., Billecocq A., Flick R., Bouloy M., Rift Valley fever virus noncoding regions of $\mathrm{L}, \mathrm{M}$ and S segments regulate RNA synthesis, Virology (2006) 351:170-179.

[98] Gear J., De Meillon B., Le Roux A.F., Kofsky R., Innes R.R., Steyn J.J., et al., Rift valley fever in South Africa; a study of the 1953 outbreak in the Orange Free State, with special reference to the vectors and possible reservoir hosts, S. Afr. Med. J. (1955) 29:514-518.

[99] Gerdes G.H., Rift Valley Fever, in: Office International des Epizooties (Ed.), Manual of diagnostic yests and vaccines for terrestrial animals (mammals, birds and bees), Chapter 2.1.8., Paris, 2004, pp. 185-194.

[100] Gerdes G.H., Rift Valley fever, Rev. Sci. Tech. Off. Int. Epizoot. (2004) 23:613-623. 
[101] Gerrard S.R., Nichol S.T., Characterization of the Golgi retention motif of Rift Valley fever virus GN glycoprotein, J. Virol. (2002) 76:12200-12210.

[102] Gerrard S.R., Li L., Barrett A.D., Nichol S.T., Ngari virus is a Bunyamwera virus reassortant that can be associated with large outbreaks of hemorrhagic fever in Africa, J. Virol. (2004) 78:8922-8926.

[103] Gerrard S.R., Bird B.H., Albarino C.G., Nichol S.T., The NSm proteins of Rift Valley fever virus are dispensable for maturation, replication and infection, Virology (2007) 359:459-465.

[104] Giorgi C., Accardi L., Nicoletti L., Gro M.C., Takehara K., Hilditch C., et al., Sequences and coding strategies of the S RNAs of Toscana and Rift Valley fever viruses compared to those of Punta Toro, Sicilian sandfly fever, and Uukuniemi viruses, Virology (1991) 180:738-753.

[105] Gorchakov R., Volkova E., Yun N., Petrakova O., Seth Linde N., Paessler S., et al., Comparative analysis of the alphavirus-based vectors expressing Rift Valley fever virus glycoproteins, Virology (2007) $366: 212-225$.

[106] Gro M.C., Di Bonito P., Accardi L., Giorgi C., Analysis of 3' and 5' ends of N and NSs messenger RNAs of Toscana Phlebovirus, Virology (1992) 191:435-438.

[107] Habjan M., Penski N., Spiegel M., Weber F., T7 RNA polymerase-dependent and -independent systems for cDNA-based rescue of Rift Valley fever virus, J. Gen. Virol. (2008) 89:2157-2166.

[108] Habjan M., Penski N., Wagner V., Spiegel M., Overby A.K., Kochs G., et al., Efficient production of Rift Valley fever virus-like particles: The antiviral protein MxA can inhibit primary transcription of bunyaviruses, Virology (2009) 385:400-408.

[109] Habjan M., Pichlmair A., Elliott R.M., Overby A.K., Glatter T., Gstaiger M., et al., NSs protein of Rift Valley fever virus induces the specific degradation of the double-stranded RNA-dependent protein kinase (PKR), J. Virol. (2009) 83:4365-4375.

[110] Hanotte O., Bradley D.G., Ochieng J.W., Verjee Y., Hill E.W., Rege J.E., African pastoralism: genetic imprints of origins and migrations, Science (2002) 296:336-339.

[111] Harrington D.G., Lupton H.W., Crabbs C.L., Peters C.J., Reynolds J.A., Slone T.W. Jr, Evaluation of a formalin-inactivated Rift Valley fever vaccine in sheep, Am. J. Vet. Res. (1980) 41:1559-1564.

[112] Heise M.T., Whitmore A., Thompson J., Parsons M., Grobbelaar A.A., Kemp A., et al., An alphavirus replicon-derived candidate vaccine against
Rift Valley fever virus, Epidemiol. Infect. (2009) 137:1309-1318.

[113] Henderson B.E., McCrae A.W.R., Kirya B.G., Ssenkubuge Y., Sempala S.D.K., Arbovirus epizootics affecting man, mosquitoes and vertebrates at Lunyo, Uganda 1968, Ann. Trop. Med. Parasitol. (1972) 66:343-355.

[114] Holman D.H., Penn-Nicholson A., Wang D., Woraratanadharm J., Harr M.K., Luo M., et al., A complex adenovirus-vectored vaccine against Rift Valley fever virus protects mice against lethal infection in the presence of preexisting vector immunity, Clin. Vaccine Immunol. (2009) 16:1624-1632.

[115] Hoogstraal H., Meegan J.M., Khalil G.M., The Rift Valley fever epizootic in Egypt 1977-78, II. Ecological and entomological studies, Trans. R. Soc. Trop. Med. Hyg. (1979) 73:624-629.

[116] Horsfall W.R., Mosquitoes: their bionomics and relation to disease, Hafner Pub. Co., New York, 1972.

[117] Hubbard K.A., Baskerville A., Stephenson J.R., Ability of a mutagenized virus variant to protect young lambs from Rift Valley fever, Am. J. Vet. Res. (1991) $52: 50-55$

[118] Huiskonen J.T., Overby A.K., Weber F., Grunewald K., Electron cryo-microscopy and single-particle averaging of Rift Valley fever virus: evidence for GN-GC glycoprotein heterodimers, J. Virol. (2009) $83: 3762-3769$.

[119] Hunter P., Erasmus B.J., Vorster J.H., Teratogenicity of a mutagenised Rift Valley fever virus (MVP 12) in sheep, Onderstepoort J. Vet. Res. (2001) 69:95-98.

[120] Hutchinson K.L., Peters C.J., Nichol S.T., Sin Nombre virus mRNA synthesis, Virology (1996) 224:139-149.

[121] Ibrahim M.S., Turell M.J., Knauert F.K., Lofts R.S., Detection of Rift Valley fever virus in mosquitoes by RT-PCR, Mol. Cell. Probes (1997) 11:49-53.

[122] Ikegami T., Peters C.J., Makino S., Rift Valley fever virus nonstructural protein NSs promotes viral RNA replication and transcription in a minigenome system, J. Virol. (2005) 79:5606-5615.

[123] Ikegami T., Won S., Peters C.J., Makino S., Rift Valley fever virus NSs mRNA is transcribed from an incoming anti-viral-sense S RNA segment, J. Virol. (2005) 79:12106-12111.

[124] Ikegami T., Won S., Peters C.J., Makino S., Rescue of infectious Rift Valley fever virus entirely from cDNA, analysis of virus lacking the NSs gene, and expression of a foreign gene, J. Virol. (2006) 80:2933-2940 
[125] Ikegami T., Won S., Peters C.J., Makino S., Characterization of Rift Valley fever virus transcriptional terminations, J. Virol. (2007) 81:8421-8438.

[126] Ikegami T., Makino S., Rift Valley fever vaccines, vaccine (2009) 27:D69-72.

[127] Ikegami T., Narayanan K., Won S., Kamitani W., Peters C.J., Makino S., Dual functions of Rift Valley fever virus NSs protein: inhibition of host mRNA transcription and post-transcriptional downregulation of protein kinase PKR, Ann. NY Acad. Sci. (2009) 1171:E75-85.

[128] Ikegami T., Narayanan K., Won S., Kamitani W., Peters C.J., Makino S., Rift Valley fever virus NSs protein promotes post-transcriptional downregulation of protein kinase PKR and inhibits eIF2alpha phosphorylation, PLoS Pathog. (2009) 5:e1000287.

[129] Ito N., Takayama-Ito M., Yamada K., Hosokawa J., Sugiyama M., Minamoto N., Improved recovery of rabies virus from cloned cDNA using a vaccinia virus-free reverse genetics system, Microbiol. Immunol. (2003) 47:613-617.

[130] Jansen van Vuren P., Potgieter A.C., Paweska J.T., van Dijk A.A., Preparation and evaluation of a recombinant Rift Valley fever virus $\mathrm{N}$ protein for the detection of IgG and IgM antibodies in humans and animals by indirect ELISA, J. Virol. Methods (2007) 140:106-114.

[131] Jansen van Vuren P., Paweska J.T., Laboratory safe detection of nucleocapsid protein of Rift Valley fever virus in human and animal specimens by a sandwich ELISA, J. Virol. Methods (2009) 157:15-24.

[132] Jenkins G.M., Rambaut A., Pybus O.G., Holmes E.C., Rates of molecular evolution in RNA viruses: a quantitative phylogenetic analysis, J. Mol. Evol. (2002) 54:156-165.

[133] Johnson B.K., Chanas A.C., el-Tayeb E., AbdelWahab K.S., Sheheta F.A., Mohamed A.E.-D., Rift Valley fever in Egypt, 1978, Lancet (1978) 2:745.

[134] Jupp P.G., McIntosh B.M., Thompson D.L., Isolation of Rift Valley fever virus from Aedes (Neomelaniconion) circumluteolus and luteolateralis collected during an outbreak in cattle in the coastal region of Natal, South Africa, S. Afr. J. Sci. (1983) 79:377.

[135] Jupp P.G., Cornel A.J., Vector competence tests with Rift Valley fever virus and five South African species of mosquito, J. Am. Mosq. Control Assoc. (1988) 4:4-8.

[136] Jupp P.G., Kemp A., The potential for dengue in South Africa: vector competence tests with dengue
1 and 2 viruses and 6 mosquito species, Trans. R. Soc. Trop. Med. Hyg. (1993) 87:639-643.

[137] Jupp P.G., The ecology of West Nile virus in South Africa and the occurence of outbreaks in humans, Ann. NY Acad. Sci. (2001) 951:143-152.

[138] Jupp P.G., Kemp A., Grobbelaar A., Leman P., Burt F.J., Alahmed A.M., et al., The 2000 epidemic of Rift Valley fever in Saudi Arabia: Mosquito vector studies, Med. Vet. Entomol. (2002) 16:245-252.

[139] Kamal S.A., Pathological studies on postvaccinal reactions of Rift Valley fever in goats, Virol. J. (2009) 6:94.

[140] Kasari T.R., Carr D.A., Lynn T.V., Weaver J.T., Evaluation of pathways for release of Rift Valley fever virus into domestic ruminant livestock, ruminant wildlife, and human populations in the continental United States, J. Am. Vet. Med. Assoc. (2008) 232:514-529.

[141] Keefer G.V., Zebarth G.L., Allen W.P., Susceptibility of dogs and cats to Rift Valley fever by inhalation or ingestion of virus, J. Infect. Dis. (1972) 125:307-309.

[142] Kitchen S.F., Laboratory infections with the virus of Rift Valley fever, Am. J. Trop. Med. Hyg. (1934) 14:547-564.

[143] Klein F., Walker J.S., Mahlandt B.G., Carter R.C., Orlando M.D., Weirether F.J., Lincoln R.E., Interacting factors that influence long-term storage of live Pasteurella tularensis vaccine and Rift Valley fever virus, Appl. Microbiol. (1969) 17:427-434.

[144] Kokernot R.H., Heymann C.S., Muspratt J., Wolstenholme B., Studies on arthropod-borne viruses of Tongaland. V. Isolation of Bunyamwera and Rift Valley fever viruses from mosquitoes, S. Afr. J. Med. Sci. (1957) 22:71-80.

[145] Kortekaas J., Dekker A., de Boer S.M., Weerdmeester K., Vloet R.P., Wit A.A., et al., Intramuscular inoculation of calves with an experimental Newcastle disease virus-based vector vaccine elicits neutralizing antibodies against Rift Valley fever virus, Vaccine (2010) 28:2271-2276.

[146] Labuda M., Nuttall P.A., Tick-borne viruses, Parasitology (2004) 129:S221-S245.

[147] Lagerqvist N., Naslund J., Lundkvist A., Bouloy M., Ahlm C., Bucht G., Characterisation of immune responses and protective efficacy in mice after immunisation with Rift Valley fever virus cDNA constructs, Virol. J. (2009) 6:6.

[148] Lappin D.F., Nakitare G.W., Palfreyman J.W., Elliott R.M., Localization of Bunyamwera bunyavirus 
G1 glycoprotein to the Golgi requires association with G2 but not with NSm, J. Gen. Virol. (1994) 75:34413451 .

[149] Laughlin L.W., Meegan J.M., Strausbaugh L.J., Epidemic Rift Valley fever in Egypt: Observations of the spectrum of human illness, Trans. R. Soc. Trop. Med. Hyg. (1979) 73:630-633.

[150] Le May N., Dubaele S., De Santis L.P., Billecocq A., Bouloy M., Egly J.M., TFIIH Transcription factor, a target for the Rift Valley hemorrhagic fever virus, Cell (2004) 116:541-550.

[151] Le May N., Mansuroglu Z., Leger P., Josse T., Blot G., Billecocq A., et al., A SAP30 complex inhibits IFN-beta expression in Rift Valley fever virus infected cells, PLoS Pathog. (2008) 4:0134-0144.

[152] Le Roux C.A., Kubo T., Grobbelaar A.A., van Vuren P.J., Weyer J., Nel L.H., et al., Development and evaluation of a real-time reverse transcriptionloop-mediated isothermal amplification assay for rapid detection of Rift Valley fever virus in clinical specimens, J. Clin. Microbiol. (2009) 47:645-651.

[153] Lee V.H., Isolation of viruses from field populations of Culicoides (Diptera: Ceratopogonidae) in Nigeria, J. Med. Entomol. (1979) 16:76-79.

[154] Lefèvre P.C., La fièvre de la vallée du Rift, Ann. Méd. Vét. (1989) 133:453-463.

[155] Linthicum K.G., Davies F.G., Bailey C.L., Kairo A., Mosquito species succession in a dambo in an East African forest, Mosq. News (1983) 43:464470 .

[156] Linthicum K.J., Bailey C.L., Davies F.G., Kairo A., Observations on the dispersal and survival of a population of Aedes lineatopennis (Ludlow) (Diptera: Culicidae) in Kenya, Bull. Entomol. Res. (1985) 75:661-670.

[157] Linthicum K.J., Davies F.G., Kairo A., Bailey C.L., Rift Valley fever virus (family Bunyaviridae, genus Phlebovirus). Isolations from diptera collected during an inter-epizootic period in Kenya, J. Hyg. (1985) 95:197-209.

[158] Linthicum K.J., Kaburia H.F., Davies F.G., Lindqvist K.J., A blood meal analysis of engorged mosquitoes found in Rift Valley fever epizootics area in Kenya, J. Am. Mosq. Control Assoc. (1985) 1: 93-95.

[159] Liu L., Celma C.C.P., Roy P., Rift Valley fever virus structural proteins: Expression, characterization and assembly of recombinant proteins, Virol. J. (2008) $5: 82$.

[160] Logan T.M., Linthicum K.J., Davies F.G., Binepal Y.S., Roberts C.R., Isolation of Rift Valley fever virus from mosquitoes (Diptera: Culicidae) collected during an outbreak in domestic animals in Kenya, J. Med. Entomol. (1991) 28:293-295.

[161] Lopez N., Muller R., Prehaud C., Bouloy M., The $\mathrm{L}$ protein of Rift Valley fever virus can rescue viral ribonucleoproteins and transcribe synthetic genome-like RNA molecules, J. Virol. (1995) 69:3972-3979.

[162] López N., Franze-Fernández M.T., A single stem-loop structure in Tacaribe arenavirus intergenic region is essential for transcription termination but is not required for a correct initiation of transcription and replication, Virus Res. (2007) 124:237-244.

[163] MacOwan K.D., The development of a livestock industry in Kenya, Vet. Hist. (1994) 8:29-37.

[164] Madani T.A., Al-Mazrou Y.Y., Al-Jeffri M.H., Mishkhas A.A., Al-Rabeah A.M., Turkistani A.M., et al., Rift Valley fever epidemic in Saudi Arabia: Epidemiological, clinical, and laboratory characteristics, Clin. Infect. Dis. (2003) 37:1084-1092.

[165] Magurano F., Nicoletti L., Humoral response in Toscana virus acute neurologic disease investigated by viral-protein-specific immunoassays, Clin. Diagn. Lab. Immunol. (1999) 6:55-60.

[166] Mansfield K.L., Johnson N., Phipps L.P., Stephenson J.R., Fooks A., Solomon T., Tick-borne encephalitis virus, A review of an emerging zoonosis, J. Gen. Virol. (2009) 90:1781-1794.

[167] Mansuroglu Z., Josse T., Gilleron J., Billecocq A., Leger P., Bouloy M., Bonnefoy E., Non structural NSs protein of Rift Valley Fever Virus interacts with pericentromeric DNA sequences of the host cell inducing chromosome cohesion and segregation defects, J. Virol. (2010) 84:928-939.

[168] Marechal F., Ribeiro N., Lafaye M., Güell A., Satellite imaging and vector-borne diseases: the approach of the French National Space Agency (CNES), Geospat. Health (2008) 3:1-5.

[169] Martin V., De Simone L., Lubroth J., Ceccato P., Chevalier V., Perspectives on using remotelysensed imagery in predictive veterinary epidemiology and global early warning systems, Geospat. Health (2007) 2:3-14.

[170] Martin V., Chevalier V., Ceccato P., Anyamba A., De Simone L., Lubroth J., et al., The impact of climate change on the epidemiology and control of Rift Valley fever, Rev. Sci. Tech. Off. Int. Epizoot. (2008) 27:413-426.

[171] McElroy A., Albarino C., Nichol S., Development of a RVFV ELISA that can distinguish infected from vaccinated animals, Virol. J. (2009) 6:125. 
[172] McIntosh B.M., Rift Valley fever. 1. Vector studies in the field, J. S. Afr. Vet. Assoc. (1972) 43:391-395.

[173] McIntosh B.M., Dickinson D.B., Dos Santos I., Rift Valley fever. 3. Viraemia in cattle and sheep. 4. The susceptibility of mice and hamsters in relation to transmission of virus by mosquitoes, J. S. Afr. Vet. Assoc. (1973) 44:167-169.

[174] McIntosh B.M., Jupp P.G., Anderson D., Dickinson D.B., Rift Valley fever. II. Attempts to transmit virus with seven species of mosquito, J. S. Afr. Vet. Med. Assoc. (1973) 44:57-60.

[175] McIntosh B.M., Mosquitoes as vectors of viruses in Southern Africa. Entomology Memoir, Department of Agricultural Technical Services of the Republic of South Africa, 1975, pp. 1-19.

[176] McIntosh B.M., Jupp P.G., Dos Santos I., Barnard B.J.H., Vector studies on Rift Valley fever virus in South Africa, S. Afr. Med. J. (1980) 58:127132.

[177] McIntosh B.M., Russell D., Dos Santos I., Gear J.H.S., Rift Valley fever in humans in South Africa, S. Afr. Med. J. (1980) 58:803-806.

[178] McIntosh B.M., Jupp P.G., Epidemiolological aspects of Rift Valley fever in South Africa with reference to vectors, in: Swartz T.A., Klinberg M.A., Goldblum N., Papier C.M. (Eds.), Contributions to epidemiology and biostatistics: Rift Valley fever, S. Karger AG, Basel, 1981, pp. 92-99.

[179] McIntosh B.M., Jupp P.G., Dos Santos I., Rowe A.C., Field and laboratory evidence implicating Culex zombaensis and Aedes circumluteolus as vectors of Rift Valley fever virus in coastal South Africa, S. Afr. J. Sci. (1983) 79:61-64.

[180] Meegan J., Bailey C.L., Rift Valley fever, in: Monath T.P. (Ed.), The arboviruses: Epidemiology and ecology, CRC Press Inc., Boca Raton, 1989, pp. $51-76$.

[181] Meegan J., Le Guenno B., Ksiazek T., Jouan A., Knauert F., Digoutte J.P., Peters C.J., Rapid diagnosis of Rift Valley fever: A comparison of methods for the direct detection of viral antigen in human sera, Res. Virol. (1989) 140:59-65.

[182] Meegan J.M., Khalil G.M., Hoogstraal H., Adham F.K., Experimental transmission and field isolation studies implicating Culex pipiens as a vector of Rift Valley fever virus in Egypt, Am. J. Trop. Med. Hyg. (1980) 29:1405-1410.

[183] Meegan J.M., Rift valley fever in Egypt: an overview of the epizootics in 1977 and 1978, in: Swartz T.A., Klinberg M.A., Goldblum N., Papier
C.M. (Eds.), Contributions to epidemiology and biostatistics: Rift Valley fever, S. Karger AG, Basel, 1981, pp. 100-113

[184] Mellor P.S., Hamblin C., African horse sickness, Vet. Res. (2004) 35:445-466.

[185] Miller B.R., Godsey M.S., Crabtree M.B., Savage H.M., Al-Mazrao Y., Al-Jeffri M.H., et al., Isolation and genetic characterization of Rift Valley fever virus from Aedes vexans arabiensis, Kingdom of Saudi Arabia, Emerg. Infect. Dis. (2002) 8:14921494.

[186] Mims C.A., Mason P.J., Rift Valley fever in mice. V. The properties of a haemagglutinin present in infective serum, Br. J. Exp. Pathol. (1956) 37:423433.

[187] Monath T.P., Yellow fever, in: Monath T.P. (Ed.), The arboviruses: Epidemiology and ecology, CRC Press Inc., Boca Raton, 1989, pp. 139-231.

[188] Morrill J.C., Jennings G.B., Caplen H., Turell M.J., Johnson A.J., Peters C.J., Pathogenicity and immunogenicity of a mutagen-attenuated Rift Valley fever virus immunogen in pregnant ewes, Am. J. Vet. Res. (1987) 48:1042-1047.

[189] Morrill J.C., Knauert F.K., Ksiazek T.G., Meegan J.M., Peters C.J., Rift Valley fever infection of Rhesus monkeys: Implications for rapid diagnosis of human disease, Res. Virol. (1989) 140:139-146.

[190] Morrill J.C., Carpenter L., Taylor D., Ramsburg H.H., Quance J., Peters C.J., Further evaluation of a mutagen-attenuated Rift Valley fever vaccine in sheep, Vaccine (1991) 9:35-41.

[191] Morrill J.C., McClain D.J., Epidemiology and pathogenesis of Rift Valley fever and other phleboviruses, in: Elliott R.M. (Ed.), The Bunyaviridae, Plenum Press, New York, 1996, pp. 281-293.

[192] Morrill J.C., Mebus C.A., Peters C.J., Safety of a mutagen-attenuated Rift valley fever virus vaccine in fetal and neonatal bovids, Am. J. Vet. Res. (1997) 58:1110-1114.

[193] Morrill J.C., Mebus C.A., Peters C.J., Safety and efficacy of a mutagen-attenuated Rift valley fever virus vaccine in cattle, Am. J. Vet. Res. (1997) 58:1104-1109.

[194] Morvan J., Fontenille D., Saluzzo J.F., Coulanges P., Possible rift valley fever outbreak in man and cattle in Madagascar, Trans. R. Soc. Trop. Med. Hyg. (1991) 85:108.

[195] Morvan J., Saluzzo J.F., Fontenille D., Rollin P.E., Coulanges P., Rift Valley fever on the east coast of Madagascar, Res. Virol. (1991) 142:475-482. 
[196] Morvan J., Lesbordes J.L., Rollin P.E., Mouden J.C., Roux J., First fatal case of Rift Valley fever in Madagascar, Trans. R. Soc. Trop. Med. Hyg. (1992) 86:320.

[197] Morvan J., Rollin P.E., Laventure S., Roux J., Duration of immunoglobulin M antibodies against Rift Valley fever virus in cattle after natural infection, Trans. R. Soc. Trop. Med. Hyg. (1992) 86:675.

[198] Moussa M.I., Abdel-Wahab K.S.E., Wood O.L., Experimental infection and protection of lambs with a minute plaque variant of Rift Valley fever virus, Am. J. Trop. Med. Hyg. (1986) 35:660-662.

[199] Moutailler S., Krida G., Schaffner F., Vazeille M., Failloux A.B., Potential vectors of Rift Valley fever virus in the Mediterranean region, Vector Borne Zoonotic Dis. (2008) 8:749-754.

[200] Muller R., Poch O., Delarue M., Bishop D.H.L., Bouloy M., Rift Valley fever virus L segment: correction of the sequence and possible functional role of newly identified regions conserved in RNA-dependent polymerases, J. Gen. Virol. (1994) 75:13451352.

[201] Muller R., Saluzzo J.F., Lopez N., Dreier T., Turell M., Smith J., Bouloy M., Characterization of clone 13, a naturally attenuated avirulent isolate of Rift Valley fever virus, which is altered in the small segment, Am. J. Trop. Med. Hyg. (1995) 53:405-411.

[202] Nakitare G.W., Elliott R.M., Expression of the Bunyamwera virus $M$ genome segment and intracellular localization of NSm, Virology (1993) 195:511520 .

[203] Nasher A.A.W., Shiban A.K., Al Eriyani M., Aly Bourgy A., Al Kohlani A.H., Benbrake M., et al., Outbreak of Rift Valley fever - Yemen, AugustOctober 2000, MMWR Morb. Mort. Wkly Rep. (2000) 49:1065-1066.

[204] Naslund J., Lagerqvist N., Habjan M., Lundkvist A., Evander M., Ahlm C., et al., Vaccination with virus-like particles protects mice from lethal infection of Rift Valley fever virus, Virology (2009) 385:409415.

[205] Neumann G., Kawaoka Y., Genetic engineering of influenza and other negative-strand RNA viruses containing segmented genomes, Adv. Virus Res. (1999) 53:265-300.

[206] Nguku P., Sharif S., Omar A., Nzioka C., Muthoka P., Njau J. et al., Rift Valley fever outbreak Kenya, November 2006-January 2007, MMWR Morb. Mort. Wkly Rep. (2007) 56:73-76.

[207] Nichol S.T., Beaty B.J., Elliott R.M., Goldbach R.W., Plyusnin A., Tesh R.B., The Bunyaviridae, in: Fauquet C., Mayo M.A., Maniloff L.S.M.,
Desselberger U., Ball L.A. (Eds.), Virus taxonomy. Classification and nomenclature of viruses. VIIIth report of the International Committee on Taxonomy of Viruses, Elsevier Academic Press, London, 2005, pp. 695-716.

[208] Niklasson B., Grandien M., Peters C.J., Gargan T.P. II, Detection of Rift Valley fever virus antigen by enzyme-linked immunosorbent assay, J. Clin. Microbiol. (1983) 17:1026-1031.

[209] Niklasson B., Peters C.J., Grandien M., Wood O., Detection of human immunoglobulins $\mathrm{G}$ and $\mathrm{M}$ antibodies to Rift Valley fever virus by enzyme-linked immunosorbent assay, J. Clin. Microbiol. (1984) 19:225-229.

[210] Njenga M.K., Paweska J., Wanjala R., Rao C.Y., Weiner M., Omballa V., et al., Using field qRT-PCR test to rapidly identify highly viremic Rift Valley fever cases, J. Clin. Microbiol. (2009) 47:11661171 .

[211] Olaleye O.D., Tomori O., Fajimi J.L., Schmitz H., Experimental infection of three Nigerian breeds of sheep with the Zinga strain of the Rift Valley fever virus, Rev. Elev. Med. Vet. Pays Trop. (1996) 49:6-16.

[212] Overby A.K., Pettersson R.F., Grunewald K., Huiskonen J.T., Insights into bunyavirus architecture from electron cryotomography of Uukuniemi virus, Proc. Natl Acad. Sci. USA (2008) 105:2375-2379.

[213] Paweska J.T., Burt F.J., Anthony F., Smith S.J., Grobbelaar A.A., Croft J.E., et al., IgG-sandwich and IgM-capture enzyme-linked immunosorbent assay for the detection of antibody to Rift Valley fever virus in domestic ruminants, J. Virol. Methods (2003) 113:103-112.

[214] Paweska J.T., Smith S.J., Wright I.M., Williams R., Cohen A.S., Van Dijk A.A., et al., Indirect enzyme-linked immunosorbent assay for the detection of antibody against Rift Valley fever virus in domestic and wild ruminant sera, Onderstepoort J. Vet. Res. (2003) 70:49-64.

[215] Paweska J.T., Burt F.J., Swanepoel R., Validation of IgG-sandwich and IgM-capture ELISA for the detection of antibody to Rift Valley fever virus in humans, J. Virol. Methods (2005) 124:173-181.

[216] Paweska J.T., Mortimer E., Leman P.A., Swanepoel R., An inhibition enzyme-linked immunosorbent assay for the detection of antibody to Rift Valley fever virus in humans, domestic and wild ruminants, J. Virol. Methods (2005) 127:10-18.

[217] Paweska J.T., Van Vuren P.J., Swanepoel R., Validation of an indirect ELISA based on a recombinant nucleocapsid protein of Rift Valley fever virus for the detection of IgG antibody in humans, J. Virol. Methods (2007) 146:119-124. 
[218] Paweska J.T., Van Vuren P.J., Kemp A., Buss P., Bengis R.G., Gakuya F., et al., Recombinant nucleocapsid-based ELISA for detection of IgG antibody to Rift Valley fever virus in African buffalo, Vet. Microbiol. (2008) 127:21-28.

[219] Pépin M., Paweska J., Bouloy M., Diagnostic specificity of ELISA-based tests for the detection of antibodies to Rift Valley fever virus in French ruminants, Rev. Méd. Vét. (2010) 161:104-107.

[220] Peters C.J., Anderson G.W., Pathogenesis of Rift Valley fever, Contrib. Epidemiol. Biostat. (1981) $3: 21-41$

[221] Peters C.J., Slone T.W., Inbred rat strains mimic the disparate human response to Rift Valley fever virus infection, J. Med. Virol. (1982) 10:45-54.

[222] Peters C.J., Reynolds J.A., Slone T.W., Prophylaxis of Rift Valley fever with antiviral drugs, immune serum, an interferon inducer, and a macrophage activator, Antiviral Res. (1986) 6:285-297.

[223] Peyrefitte C.N., Boubis L., Coudrier D., Bouloy M., Grandadam M., Tolou H.J., Plumet S., Real-time reverse-transcription loop-mediated isothermal amplification for rapid detection of Rift Valley fever virus, J. Clin. Microbiol. (2008) 46:3653-3659.

[224] Pfeiffer D., Pépin M., Wooldridge M., Schudel A., Baldet T., Davies G., et al., AHAW Panel Members, Opinion of the Scientific Panel on Animal Health and Welfare (AHAW) on a request from the Commission related to "The risk of a Rift Valley fever incursion and its persistence within the Community", EFSA, http://www.efsa.europa.eu, Parma (Italy), 2005, pp. 1-130.

[225] Pollitt E., Zhao J., Muscat P., Elliott R.M., Characterization of Maguari orthobunyavirus mutants suggests the nonstructural protein NSm is not essential for growth in tissue culture, Virology (2006) 348:224 232.

[226] Prehaud C., Lopez N., Blok M.J., Obry V., Bouloy M., Analysis of the 3' terminal sequence recognized by the Rift Valley fever virus transcription complex in its ambisense S segment, Virology (1997) 227:189-197.

[227] Rice R.M., Erlick B.J., Rosato R.R., Eddy G.A., Mohanty S.B., Biochemical characterization of Rift Valley fever virus, Virology (1980) 105:256-260.

[228] Ritter M., Bouloy M., Vialat P., Janzen C., Haller O., Frese M., Resistance to Rift Valley fever virus in Rattus norvegicus: Genetic variability within certain 'inbred' strains, J. Gen. Virol. (2000) 81:26832688 .

[229] Rodhain F., Albina E., André-Fontaine G., Armengaud M., Dreyfuss G., Dufour B., et al.,
Rapport sur l'évaluation du risque d'apparition et de développement des maladies animales compte tenu d'un éventuel réchauffement climatique, AFSSA, www.afssa.fr, Maisons-Alfort, 2005, pp. 1-78.

[230] Rossi C.A., Turell M.J., Characterization of attenuated strains of Rift Valley fever virus, J. Gen. Virol. (1988) 69.

[231] Sall A.A., Zanotto P.M.D.A., Zeller H.G., Digoutte J.P., Thiongane Y., Bouloy M., Variability of the $\mathrm{NS}_{\mathrm{s}}$ protein among Rift Valley fever virus isolates, J. Gen. Virol. (1997) 78:2853-2858.

[232] Sall A.A., Zanotto P.M.A., Vialat P., Sene O.K., Bouloy M., Molecular epidemiology and emergence of Rift Valley fever, Mem. Inst. Oswaldo Cruz (1998) 93:609-614.

[233] Sall A.A., Zanotto P.M.D.A., Vialat P., Sene O.K., Bouloy M.B., Origin of 1997-1998 Rift Valley fever outbreak in East Africa, Lancet (1998) 352:1596-1597.

[234] Sall A.A., Zanotto P.M.D.A., Sene O.K., Zeller H.G., Digoutte J.P., Thiongane Y., Bouloy M., Genetic reassortment of Rift Valley fever virus in nature, J. Virol. (1999) 73:8196-8200.

[235] Sall A.A., Macondo E.A., Sène O.K., Diagne M., Sylla R., Mondo M., et al., Use of reverse transcriptase PCR in early diagnosis of Rift Valley fever, Clin. Diagn. Lab. Immunol. (2002) 9:713-715.

[236] Saluzzo J.F., Smith J.F., Use of reassortant viruses to map attenuating and temperature-sensitive mutations of the Rift Valley fever virus MP-12 vaccine, Vaccine (1990) 8:369-375.

[237] Schwarz T.F., Gilch S., Pauli C., Jager G., Immunoblot detection of antibodies to Toscana virus, J. Med. Virol. (1996) 49:83-86.

[238] Sherman M.B., Freiberg A.N., Holbrook M.R., Watowich S.J., Single-particle cryo-electron microscopy of Rift Valley fever virus, Virology (2009) 387:11-15.

[239] Shoemaker T., Boulianne C., Vincent M.J., Pezzanite L., Al-Qahtani M.M., Al-Mazrou Y., et al., Genetic analysis of viruses associated with emergence of Rift Valley fever in Saudi Arabia and Yemen, 20002001, Emerg. Infect. Dis. (2002) 8:1415-1420.

[240] Shope R.E., Sather G.E., Arboviruses, in: Lenette E.H., Schmidt N.J. (Eds.), Diagnostic procedures for viral rickettsial and chlamydial infections, American Public Health Association, Washington, DC, 1979, pp. 767-814.

[241] Simons J.F., Hellman U., Pettersson R.F., Uukuniemi virus S RNA segment: ambisense coding 
strategy, packaging of complementary strands into virions, and homology to members of the genus Phlebovirus, J. Virol. (1990) 64:247-255.

[242] Sissoko D., Giry C., Gabrie P., Tarantola A., Pettinelli F., Collet L., et al., Rift Valley fever, Mayotte, 2007-2008, Emerg. Infect. Dis. (2009) 15:568-570.

[243] Smithburn K.C., Haddow A.J., Gillett J.D., Rift Valley fever; isolation of the virus from wild mosquitoes, Brit. J. Exp. Pathol. (1948) 29:107-121.

[244] Smithburn K.C., Rift Valley fever: the neurotropic adaptation of the virus and the experimental use of this modified virus as a vaccine, Brit. J. Exp. Pathol. (1949) 30:1-16.

[245] Smithburn K.C., Haddow A.J., Lumsden W.H., Rift Valley fever: transmission of the virus by mosquitoes, Brit. J. Exp. Pathol. (1949) 30:35-47.

[246] Smithburn K.C., Mahaffy A.F., et al., Rift Valley fever; accidental infections among laboratory workers, J. Immunol. (1949) 62:213-227.

[247] Spik K., Shurtleff A., McElroy A.K., Guttieri M.C., Hooper J.W., Schmaljohn C., Immunogenicity of combination DNA vaccines for Rift Valley fever virus, tick-borne encephalitis virus, Hantaan virus, and Crimean Congo hemorrhagic fever virus, Vaccine (2006) 24:4657-4666.

[248] Struthers J.K., Swanepoel R., Identification of a major non-structural protein in the nuclei of Rift Valley fever virus-infected cells, J. Gen. Virol. (1982) 60:381-384.

[249] Swanepoel R., Studies on the epidemiology of Rift Valley Fever, J. S. Afr. Vet. Assoc. (1976) 57:93-94.

[250] Swanepoel R., Blackburn N.K., Demonstration of nuclear immunofluorescence in Rift Valley fever infected cells, J. Gen. Virol. (1977) 34:557-561.

[251] Swanepoel R., Struthers J.K., Erasmus M.J., Comparison of techniques for demonstrating antibodies to Rift Valley fever virus, J. Hyg. (1986) 97:317329.

[252] Swanepoel R., Struthers J.K., Erasmus M.J., Comparative pathogenicity and antigenic cross-reactivity of Rift Valley fever and other African phleboviruses in sheep, J. Hyg. (1986) 97:331-346.

[253] Swanepoel R., Coetzer J.A., Rift Valley fever, in: Coetzer J.A., Tustin R.C. (Eds.), Infectious diseases of livestock, Oxford University Press Southern Africa, Cape Town, 2004, pp. 1037-1070.

[254] Taylor P., Swanepoel R., Observations on mosquitoes, midges and rodents during the 1978 Rift
Valley fever epizootic in Zimbabwe, Zimbabwe Vet. J. (1980) 11:44-49.

[255] Tesh R.B., Peters C.J., Meegan J.M., Studies on the antigenic relationship among phleboviruses, Am. J. Trop. Med. Hyg. (1982) 31:149-155.

[256] Theiler M., Smith H.H., The effect of prolonged cultivation in vitro upon the pathogenicity of yellow fever virus, J. Exp. Med. (1937) 65:767-786.

[257] Theiler M., Action of sodium desoxycholate on arthropod-borne viruses, Proc. Soc. Exp. Biol. Med. (1957) 96:380-382.

[258] Tolou H., Plumet S., Leparc-Goffart I., Couissinier-Paris P., Le virus de la fièvre de la vallée du Rift: évolution en cours, Méd. Trop. (2009) 69:215220.

[259] Tomori O., Clinical, virological and serological response of the West African dwarf sheep to experimental infection with different strains of Rift Valley fever virus, Res. Vet. Sci. (1979) 26:152-159.

[260] Turell M.J., Bailey C.L., Beaman J.R., Vector competence of a Houston, Texas strain of Aedes albopictus for Rift Valley fever virus, J. Am. Mosq. Control Assoc. (1988) 4:94-96.

[261] Turell M.J., Faran M.E., Cornet M., Bailey C.L., Vector competence of Senegalese Aedes fowleri (Diptera: Culicidae) for Rift Valley fever virus, J. Med. Entomol. (1988) 25:262-266.

[262] Turell M.J., Linthicum K.J., Beaman J.R., Transmission of Rift Valley fever virus by adult mosquitoes after ingestion of virus as larvae, Am. J. Trop. Med. Hyg. (1990) 43:677-680.

[263] Turell M.J., Perkins P.V., Transmission of Rift Valley fever virus by the sand fly, Phlebotomus duboscqi (Diptera: Psychodidae), Am. J. Trop. Med. Hyg. (1990) 42:185-188.

[264] Turell M.J., Presley S.M., Gad A.M., Cope S.E., Dohm D.J., Morrill J.C., Arthur R.R., Vector competence of Egyptian mosquitoes for Rift Valley fever virus, Am. J. Trop. Med. Hyg. (1996) 54:136139.

[265] Turell M.J., Lee J.S., Richardson J.H., Sang R.C., Kioko E.N., Agawo M.O., et al., Vector competence of Kenyan Culex zombaensis and Culex quinquefasciatus mosquitoes for Rift Valley fever virus, J. Am. Mosq. Control Assoc. (2007) 23:378382 .

[266] Turell M.J., Dohm D.J, Mores C.N., Terracina L., Wallette D.L. Jr, Hribar L.J., et al., Potential for North American mosquitoes to transmit Rift Valley fever virus, J. Am. Mosq. Control Assoc. (2008) 24:502-507. 
[267] Turell M.J., Linthicum K.J., Patrican L.A., Davies F.G., Kairo A., Bailey C.L., Vector competence of selected African mosquito (Diptera: Culicidae) species for Rift Valley fever virus, J. Med. Entomol. (2008) 45:102-108.

[268] Van Velden D.J.J., Meyer J.D., Olivier J., Rift Valley fever affecting humans in South Africa. A clinicopathological study, S. Afr. Med. J. (1977) 51:867-871.

[269] Vapalahti O., Kallio-Kokko H., Narvanen A., Julkunen I., Lundkvist A., Plyusnin A., et al., Human B-cell epitopes of Puumala virus nucleocapsid protein, the major antigen in early serological response, J. Med. Virol. (1995) 46:293-303.

[270] Vialat P., Muller R., Vu T.H., Prehaud C., Bouloy M., Mapping of the mutations present in the genome of the Rift Valley fever virus attenuated MP12 strain and their putative role in attenuation, Virus Res. (1997) 52:43-50.

[271] Vialat P., Billecocq A., Kohl A., Bouloy M., The S segment of Rift Valley fever phlebovirus (Bunyaviridae) carries determinants for attenuation and virulence in mice, J. Virol. (2000) 74:1538-1543.

[272] Vignolles C., Lacaux J.P., Tourre Y.M., Bigeard G., Ndione J.A., Lafaye M., Rift Valley fever in a zone potentially occupied by Aedes vexans in Senegal: dynamics and risk mapping, Geospat. Health (2009) 3:211-220.

[273] Von Bonsdorff C.H., Pettersson R., Surface structure of Uukuniemi virus, J. Virol. (1975) 16:1296-1307.

[274] Walker J.S., Remmele N.S., Carter R.C., Mitten J.Q., Schuh L.G., Stephen E.L., Klein F., The clinical aspects of Rift Valley fever virus in household pets. I. Susceptibility of the dog, J. Infect. Dis. (1970) 121:918.

[275] Walker J.S., Stephen E.L., Remmele N.S., Carter R.C., Mitten J.Q., Schuh L.G., Klein F., The clinical aspects of Rift Valley fever virus in household pets. II. Susceptibility of the cat, J. Infect. Dis. (1970) 121:19-24.

[276] Wallace D.B., Viljoen G.J., Immune responses to recombinants of the South African vaccine strain of lumpy skin disease virus generated by using thymidine kinase gene insertion, Vaccine (2005) 23:3061-3067.

[277] Wallace D.B., Ellis C.E., Espach A., Smith S.J., Greyling R.R., Viljoen G.J., Protective immune responses induced by different recombinant Vaccine regimes to Rift Valley fever, Vaccine (2006) 24:71817189 .
[278] Wasmoen T.L., Kakach L.T., Collett M.S., Rift Valley fever virus $M$ segment: cellular localization of M segment-encoded proteins, Virology (1988) $166: 275-280$.

[279] Weaver S.C., Host range, amplification and arboviral disease emergence, Arch. Virol. (2005) S33S44.

[280] Weaver S.C., Reisen W.K., Present and future arboviral threats, Antiviral Res. (2010) 85:328-345.

[281] Weber F., Dunn E.F., Bridgen A., Elliott R.M., The Bunyamwera virus nonstructural protein NSs inhibits viral RNA synthesis in a minireplicon system, Virology (2001) 281:67-74.

[282] Weinbren M.P., Williams M.C., Haddow A.J., A variant of Rift Valley fever virus, S. Afr. Med. J. (1957) 31:951-957.

[283] White D.M., Wilson W.C., Blair C.D., Beaty B.J., Studies on overwintering of bluetongue viruses in insects, J. Gen. Virol. (2005) 86:453-462.

[284] Whitlow R., Some morphological characteristics of dambo features in Zimbabwe, Transactions of the Zimbabwe Scientific Association (1984) 62:1-15.

[285] WHO, Outbreaks of Rift Valley fever in Kenya, Somalia and United Republic of Tanzania, December 2006-April 2007, Weekly Epidemiol. Rec. (2007) 82:169-178.

[286] Williams M.C., Woodall J.P., Corbet P.S., Haddow A.J., An outbreak of Rift Valley fever occurring near Entebbe: entomological studies and further isolations, East African Virus Research Institute Reports (1960) 10:24-25.

[287] Won S., Ikegami T., Peters C.J., Makino S., NSm protein of Rift Valley fever virus suppresses virus-induced apoptosis, J. Virol. (2007) 81:1333513345.

[288] Xu F., Liu D., Nunes M.R., Da Rosa A.P., Tesh R.B., Xiao S.Y., Antigenic and genetic relationships among Rift Valley fever virus and other selected members of the genus Phlebovirus (Bunyaviridae), Am. J. Trop. Med. Hyg. (2007) 76:1194-1200.

[289] Yedloutschnig R.J., Dardiri A.H., Walker J.S., Persistence of Rift valley fever virus in the spleen, liver, and brain of sheep after experimental infection, in: Swartz T.A., Klinberg M.A., Goldblum N., Papier C.M. (Eds.), Contributions to epidemiology and biostatistics: Rift Valley fever, S. Karger AG, Basel, 1981, pp. 72-76.

[290] Young A., Tropical soils and soil survey, Cambridge University Press, Cambridge, 1976. 
[291] Zabransky R.J., Is Rift Valley fever a threat in the United States?, Clin. Microbiol. Newsl. (2005) 27:41.

[292] Zaki A., Coudrier D., Yousef A.I., Fakeeh M., Bouloy M., Billecocq A., Production of monoclonal antibodies against Rift Valley fever virus: Application for rapid diagnosis tests (virus detection and ELISA) in human sera, J. Virol. Methods (2006) 131:34-40.
[293] Zeller H.G., Fontenille D., Traore-Lamizana M., Thiongane Y., Digoutte J.P., Enzootic activity of rift valley fever virus in Senegal, Am. J. Trop. Med. Hyg. (1997) 56:265-272.

[294] Zhao J., Kim K.D., Yang X., Auh S., Fu Y.X., Tang H., Hyper innate responses in neonates lead to increased morbidity and mortality after infection, Proc. Natl Acad. Sci. USA (2008) 105:7528-7533. 